ENERGY EFFICIENT HOUSE USING GROUND SOURCE HEAT PUMP: MATHEMATICAL MODEL OF THERMAL IMBALANCE OF SOIL AROUND THE GROUND LOOP

By

Md. Shahidul Islam

B.Sc Eng, Dhaka, Bangladesh

December, 1993.

\author{
A project \\ presented to Ryerson University \\ in partial fulfillment of the \\ requirements for the degree of \\ Master of Engineering \\ in the Program of
}

Electrical and Computer Engineering

Toronto, Ontario, Canada, 2016.

CMd Shahidul Islam, 2016 


\section{AUTHOR'S DECLARATION}

\section{AUTHOR'S DECLARATION FOR ELECTRONIC SUBMISSION OF A PROJECT}

I hereby declare that I am the sole author of this project. This is a true copy of the project, including any required final revisions, as accepted by my examiners.

I authorize Ryerson University to lend this project to other institutions or individuals for the purpose of scholarly research.

I further authorize Ryerson University to reproduce this project by photocopying or by other means, in total or in part, at the request of other institutions or individuals for the purpose of scholarly research.

I understand that my project may be made electronically available to the public 


\title{
ENERGY EFFICIENT HOUSE USING GROUND SOURCE HEAT PUMP: MATHEMATICAL MODEL OF THERMAL IMBALANCE OF SOIL AROUND THE GROUND LOOP
}

\author{
Md Shahidul Islam \\ Master of Engineering in Electrical and Computer Engineering \\ Ryerson University, 2016
}

\begin{abstract}
:
Houses in Canada are now energy efficient than ever. A more energy efficient house is more comfortable to live, saves more money in the utility bill and reduces the greenhouse gas emission. Ground Source Heat Pump (GLHP or HSHP) sometimes called Geothermal Heatpump is used to reduce the energy consumption further. Burying a loop of polyethylene pipe in the ground around the house is like owning its own energy well. The GSHP extracts heat from the ground in the heating season (winter) and rejects heat to the ground in cooling season (summer). The difference between the extracted heat and the rejected heat is called thermal imbalance that leads the soil toward thermal degradation which is site-specific and depends on region's climate, soil conditions at the site of the ground loop, and the sizing of the ground loop. The purpose of this study is to numerical analysis of the energy use, GSHP saving, mathematical modelling of thermal imbalance and find ways to reduce the thermal imbalance of the soil of a site in Canada.
\end{abstract}




\section{Acknowledgements}

At the beginning I would like to thank my thesis advisor Professor Kaamran Raahemifar of the Electrical and Computer Engineering Department at Ryerson University. Professor Kaamran was highly cooperative and helpful whenever I ran into a trouble of understanding a concept or had a question about my research or writing the thesis report. He guided me in the right direction whenever he thought I needed it. He wanted this paper to be my own work with innovation and research.

I would also like to thank Professor Richard Cheung of the Electrical and Computer Engineering Department at Ryerson University as the second reader of this thesis. I am grateful to him for his thoughtful comments on this thesis.

Finally, I would like to express my gratitude to my course mates for providing me with support and continuous encouragement throughout these years. Their encouragement helped me in researching and writing this thesis. I would like to share this accomplishment with everyone who gave me support. Thank you.

Author

Md Shahidul Islam 


\section{Table of Contents:}

Author's Declaration ............................................................................. ii

Abstract ............................................................................................................

Acknowledgements ........................................................................................... iv

1.0 Introduction - Heating and Cooling with a Heat Pump ................................................. 1

1.1 A modern Canadian house from energy point of view ......................................... 3

1.2 Energy consumption by fuels for heating/cooling.............................................. 5

1.3 Subject House in our study ............................................................................. 5

2.0 Energy Systems installed in Canadian houses ............................................................ 8

2.1 Existing Energy Systems in the house ................................................................. 8

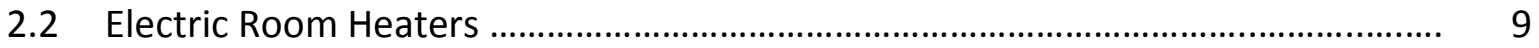

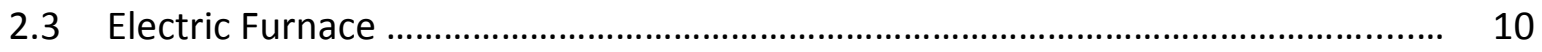

2.4 Central refrigeration Cooling System ............................................................... 10

2.5 The integrated heating/cooling system in the house........................................... 12

2.6 Domestic Hot Water system in the house ........................................................... 12

2.7 Lighting and Appliance Loads of the House........................................................ 13

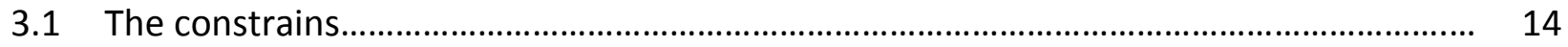

3.2 The overall heat loss and Heating Energy Requirement ....................................... 15

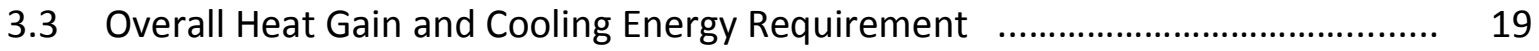

3.4 Domestic Hot Water Requirement....................................................................... 20

3.5 Appliance Loads of the House................................................................................... 20

4.0 Calculation of Energy Consumption of the Installed Systems ........................................ 21

4.1 Calculated Annual Energy Consumption by The Existing Systems......................... 22

5.0 The Four-Steps of Decision-Making Process For Energy Efficient Home ....................... 23

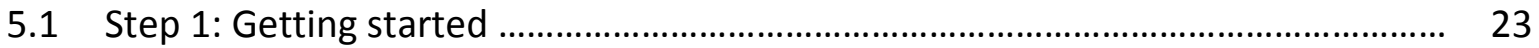

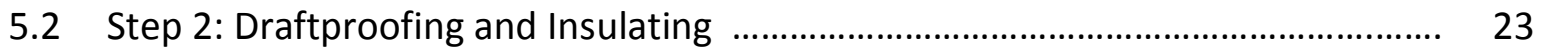

5.3 Step 3: Selecting the energy source .................................................................... 23

5.4 Step 4: Selecting or improving the heat distribution system ................................ 24

6.0 Proposed Alternate System 1 - Ground Loop Heat Pump.................................................. 26 
6.1 System description ...................................................................................... 26

6.2 Operating principle of GLHP ......................................................................... 28

6.3 Design Condition ......................................................................................... 29

6.4 Installation Considerations ................................................................................. 30

6.5 Major Benefits of Earth-Energy Systems .............................................................. 30

6.6 Operating Costs ............................................................................................. 31

6.7 Factors Affecting Heating Cost Comparisons......................................................... 31

6.8 Supplementary Heating Systems ..................................................................... 32

7.1 Ground Source Heatpump System Mathematical Model.................................................. 33

7.2 Numerical Simulation and Performance Analysis.................................................... 41

7.3 Annual Energy Consumption by the Systems......................................................... 48

8.0 Results comparison .................................................................................................. 49

9.0 Annual Heat Imbalance: Methods to reduce.................................................................... 50

9.1 GSHP with Solar thermal collector ....................................................................... 51

9.2 Solar assisted ground source heat pump with latent heat storage system............ 52

10.0 Executive Summary .................................................................................................... 53

11.0 Conclusion ......................................................................................................... 54

\section{Appendices:}

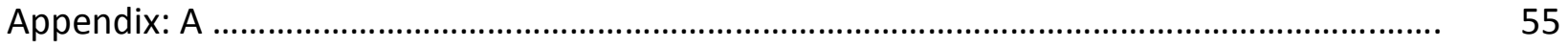

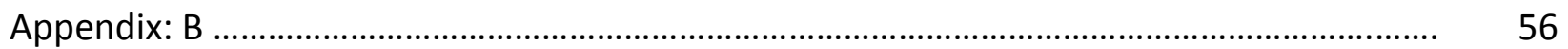

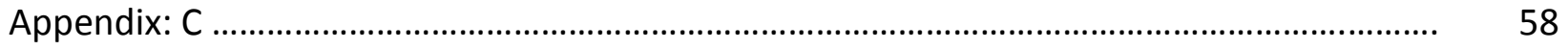

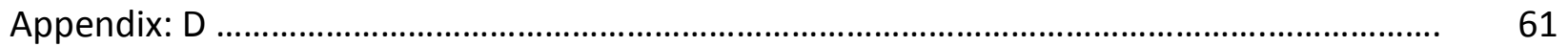

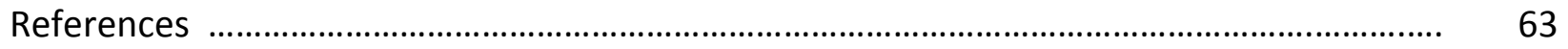

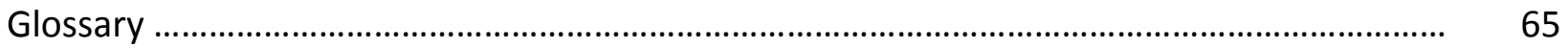




\subsection{Introduction}

The energy requirement of the house is mostly dependent on electricity. Heating and DHW is partly done by natural gas burning. Almost every house in Canada requires climate control. There are three types of heating/cooling requirements in a building which are space heating, space cooling and domestic hot water. In early days of house construction the heating was performed by burning wood, cooling was done by natural circulation of air or evaporative cooling. Hot water was produced by heating water in bowl. Now a day space heating and domestic hot water is performed by gas or oil heater or electric heating. Cooling is performed by mechanical refrigeration system.

The average energy consumption of Canadian home is reduced by applying modern building manufacturing techniques. The he minimum requirement could not be lowered to zero. The purpose of this study is to find source of free energy to reduce the electric and gas energy consumption further.

The heat in the sunlight is absorbed by the earth which is direct absorption of energy. There are some other kinds of indirect absorption. The heat in the sun evaporates water from the ocean, river, lakes and all other water bodies. This evaporated water eventually falls back to earth in the form of rain and filters deep into the ground. The earth core temperature is $6,000^{\circ} \mathrm{C}$ in the centre. About $70 \mathrm{~m}$ depth the temperature is about $15^{\circ} \mathrm{C}$ throughout the year. This could be a good source for heating in winter and cooling in summer. The only challenge is to move this free energy from the ground into the house. This could be done either by pumping water from a natural or artificial well (open loop) or by pumping a heat transfer fluid to exchange the heat through a underground horizontal or vertical circuit of piping(closed loop). This heat transfer fluid absorbs the heat from the ground water or soil and transfers it to the heat pump. In cooling season the heat can be dumped in the same way. Heat pump then circulates a second loop into the house for space heating/cooling. If there is pond, lake or river near the house, we can use the water of this water body to extract heat from this excellent source of free energy. 
The capacity of ground-source heat pumps in Canada is determined by the heating load of the building. Moreover, in some areas the GSHP will be used only for heating as there may be no seasonal cooling need. So the ground loop is used for heat extraction for the purpose of space heating and there is almost no heat rejection to the ground which would be needed if space cooling was required.

This difference in heat extraction and heat rejection presents two disadvantages for GSHP in cold climates: heat is required to be extracted from relatively cold ground and is not being balanced by heat rejection used for space cooling.

The entering water temperature (EWT) is one of the most important factors determining the COP of a GSHP. The EWT is a function of the ground temperature in which the ground loop is placed. In heating season, a higher soil temperature will provide a higher EWT which will lead to a more efficient GSHP operation. The range of ground temperatures in Canada is substantially lower.

In this study our goal is to find suitable method of using this geothermal energy and quantify the savings of energy by adopting different techniques. The heat imbalance will also be calculated and methods to minimize the heat imbalance will be investigated. Softwares will be used to calculate the heating/cooling and DHW needs. Two mostly used softwares are RETScreen, HOT 2000 from Natural Resources Canada and HVAC Calc (Institutional version). A simulation software TRN Build 2.0 will be used for simulation of the heat imbalance. 


\subsection{A modern Canadian house from energy point of view}

A modern Canadian house built after 2000 is very efficient from energy point of view. Several manufacturing techniques are already adopted to make it more efficient including:

- Insulating foundations and building envelops with high $\mathrm{R}$ value insulations

- $\quad$ Insulating ceiling and walls with high $\mathrm{R}$ value insulations

- Using energy efficient doors and windows

- $\quad$ Using energy efficient electrical equipments

- $\quad$ Reducing air filtrations

- Harvesting solar heat and light gain

- $\quad$ Shading the building envelope etc.

Electricity is been used by Canadian houses for the lighting and powering appliances. A significant portion of houses (over 37\%) use electricity for heating. Households consumed 144 TWh of electricity in 2007, with average electricity consumption of 11,000 kWh per household.

Natural gas can be used for home heating, water heating, and also to fuel other large appliances

such as stoves, clothes dryers and barbecues. Total household natural gas consumption was $587,183 \mathrm{TJ}$ in 2007 . Households that used natural gas consumed on average $92 \mathrm{GJ}$ of this fuel. 


\subsection{Energy consumption by fuels in Canadian houses}

About $56 \%$ of households use gas furnace for the heating need followed by $24 \%$ of households use electric Baseboard. The remaining households use other sources like heating stoves or boilers powered by coal or wood firing.

This pattern resembles the whole country but is different for the provinces. Gas furnace heating is dominant in Ontario (76\%), Prairies (85\%) and BC (56\%) whereas electric Baseboard heating is common in Quebec (61\%) and BC (24\%). Almost half (47\%) Canadian houses use natural gas and $37 \%$ use electricity as their main heating fuel.

\subsection{Subject House in our study}

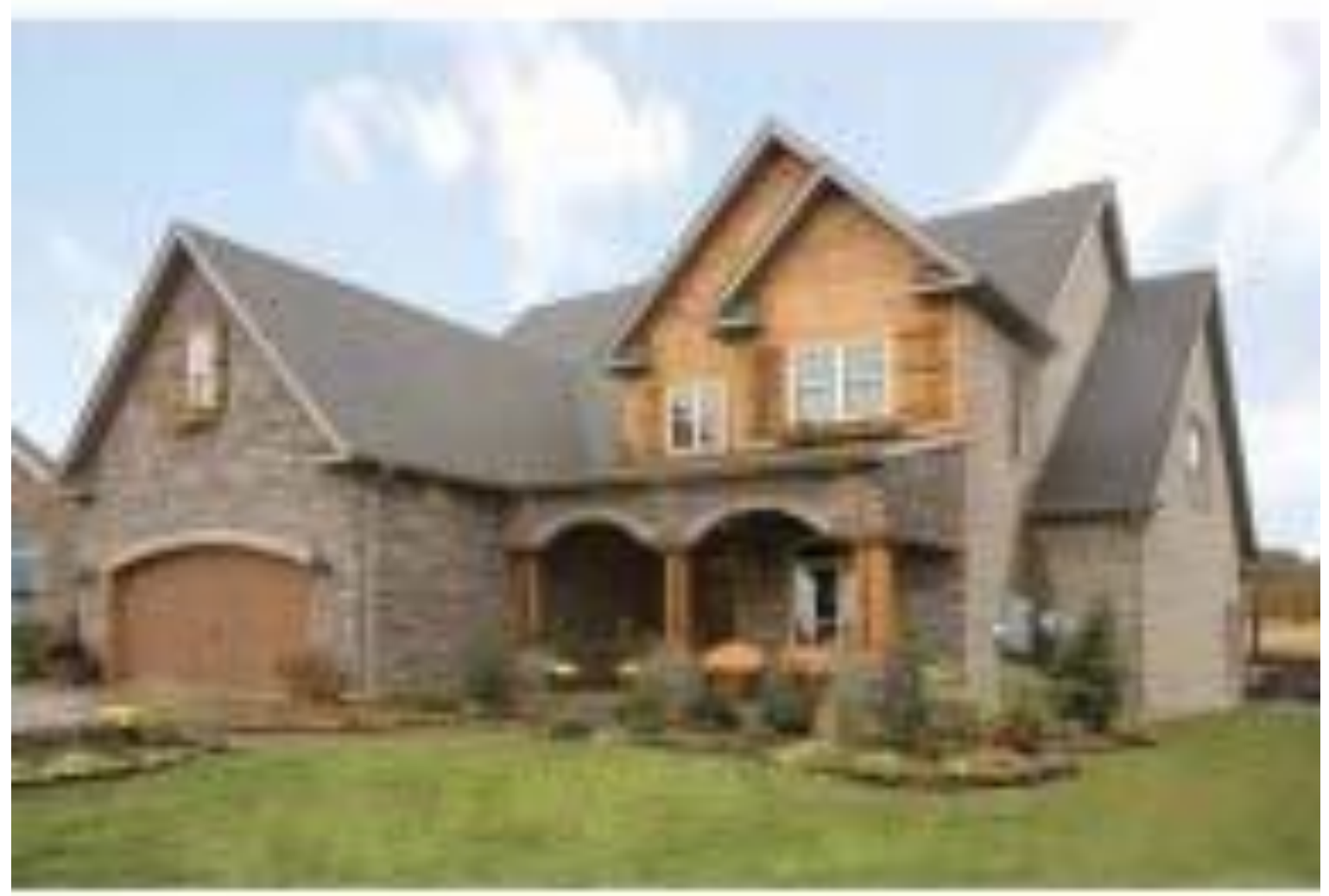


House Plan is as follows:

Level 1

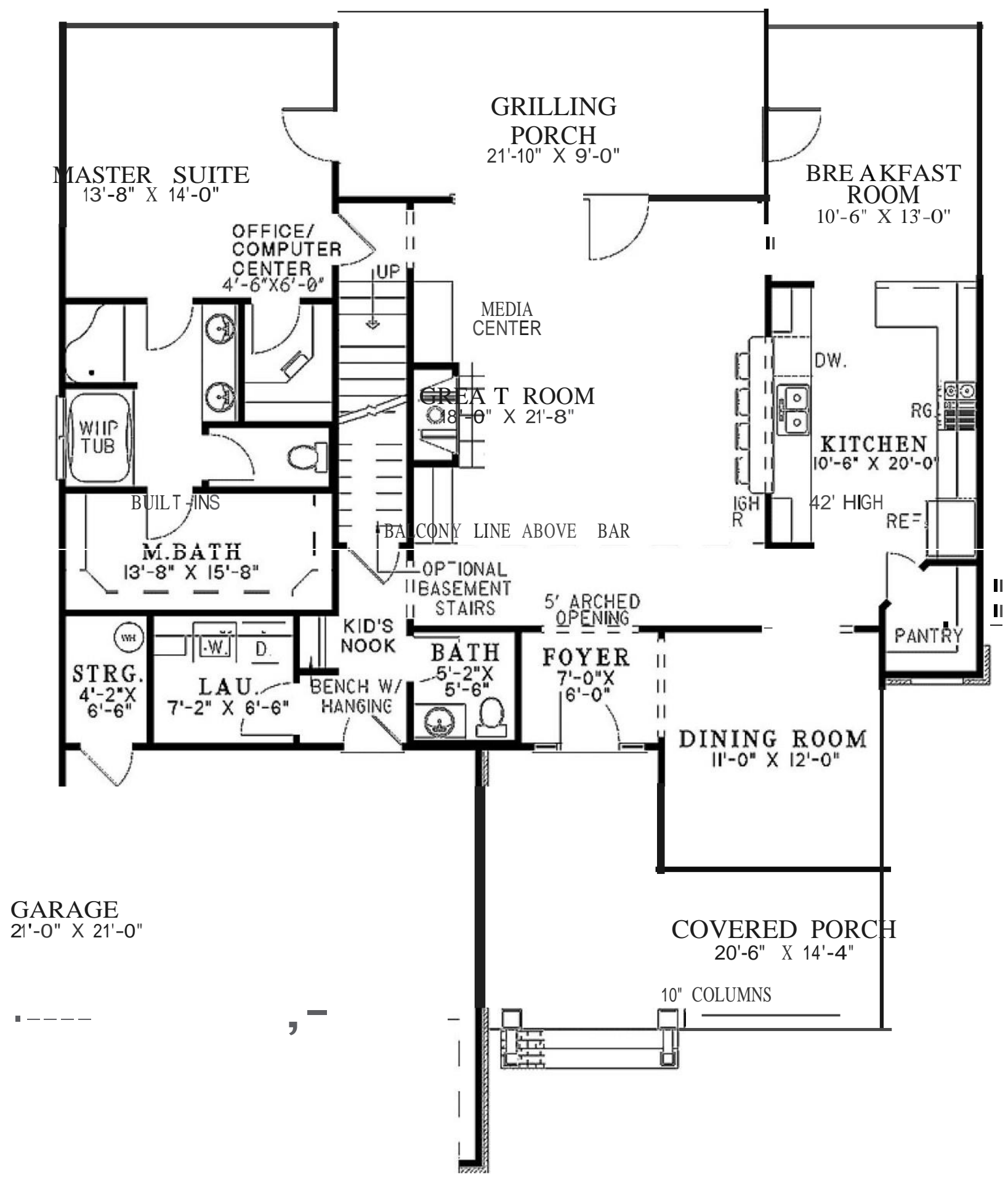




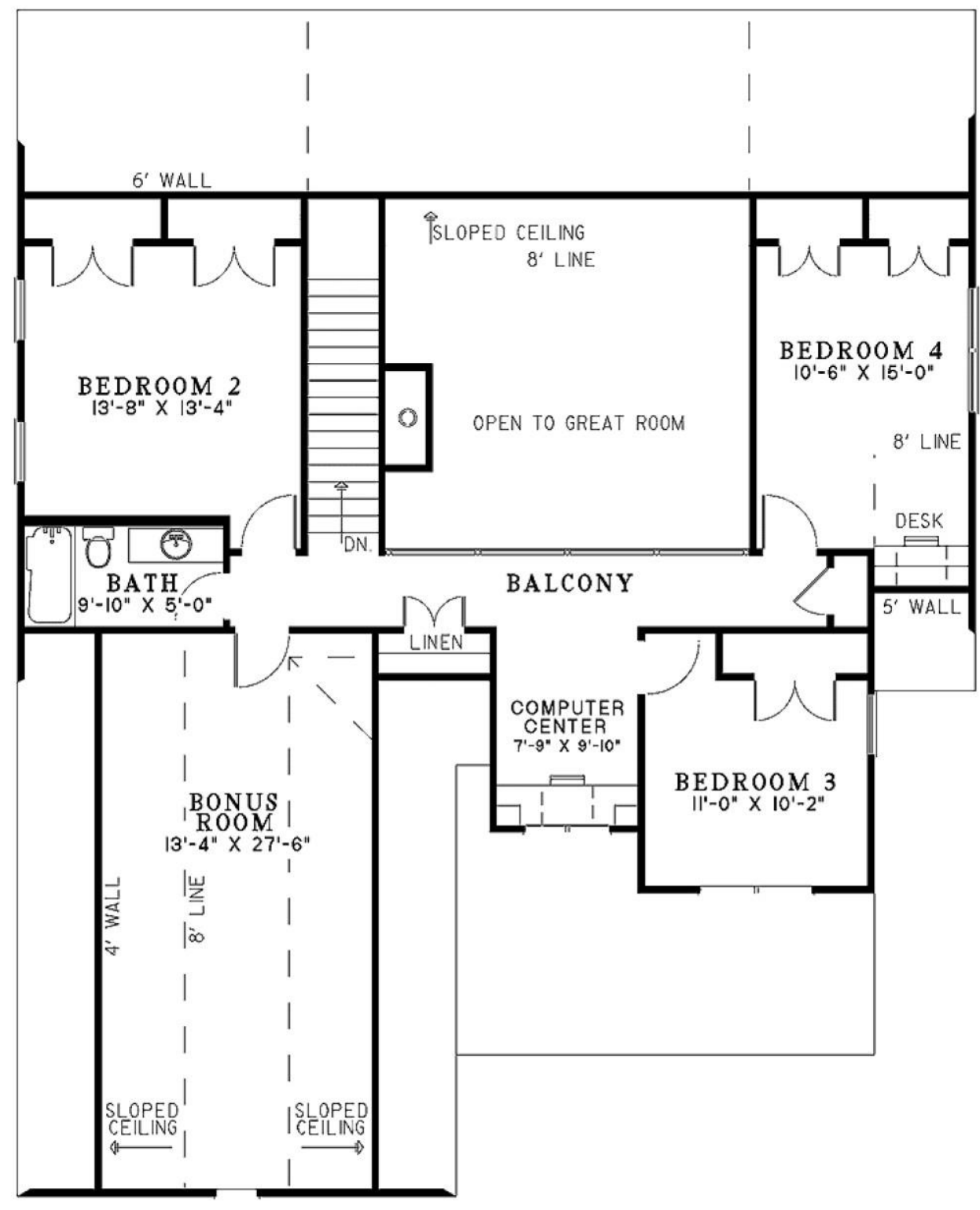

Our subject house is within Toronto. Natural gas is not readily available. It is a single detached house with two stories. First floor is 1595 square feet, second floor is 875 square feet with a total living area of 2470 square feet including a bonus space of 389 sq. feet. The house has 4 bedrooms, 3 bathrooms and two garage bays (Floor plan is attached in the appendix). The house was built in 2012 adopting all modern construction techniques. The house is highly energy efficient. The as built heating source is electric Baseboard heater, cooling source is refrigerant cooling and Electric Boiler as the Domestic Hot Water need. Occupants of the house are 2 Adults for $50.0 \%$ of the time and 2 Children for $50.0 \%$ of the time. 


\subsection{Energy Systems Installed in Canadian houses:}

Two thirds of the energy used in Canadian homes goes to space heating because of its cold climate. A residential dwelling should be kept at a minimum of 21 degrees Celsius between September 15 and June 1 of each year. There are several possible options for space heating furnaces, boilers, heat pumps, baseboard heaters - and a choice of different energy sources, e.g., oil, gas, propane, electricity or the sun. Some of the houses even use two or more types of heating and/or energy.

\section{Residential energy use in Canada by activity, 2010}

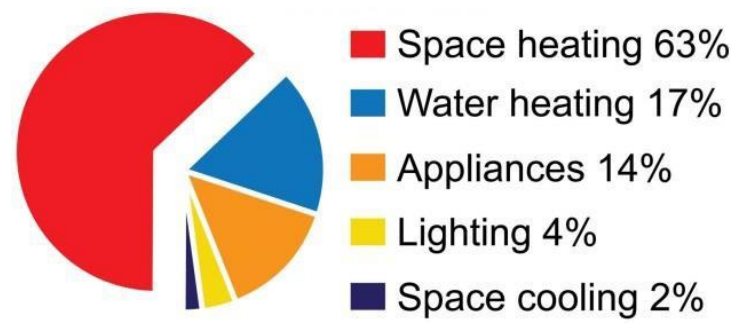

Source: Energy Efficiency Trends in Canada 1990-2010, Natural Resources Canada.

Whatever heating option is chosen, it is required to consider beside the capital investment the energy cost to run the heating system over its lifetime. To determine the operating costs it is required to consider the three factors: the annual heating requirement, fuel type and price, and equipment efficiency.

\subsection{Existing Energy Systems in the House}

The existing system in the house is considered as Electric Furnace/Heaters for Heating, Central Refrigeration Air Conditioning System for cooling and Electric Boiler for Domestic Hot Water needs.

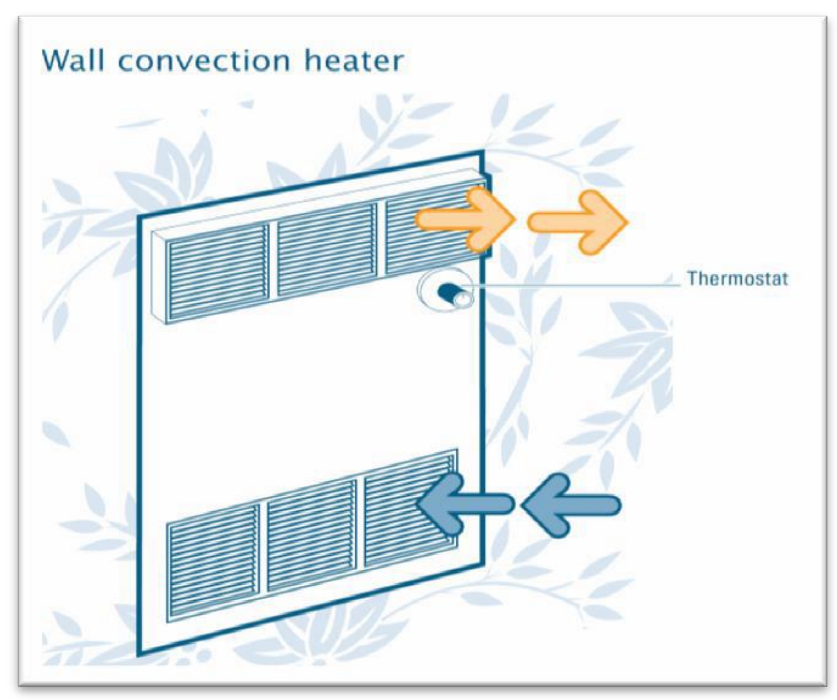




\subsection{Electric Room Heaters}

Electric room heaters are locally installed in each room and are individually controlled. These heaters are automatically controlled by the thermostat which can be located within the units themselves or be mounted on a wall wired connected. All modern room heaters are equipped with built-in controls to prevent overheating in the worst case of airflow is restricted.

The most common type of electric room heater is the baseboard heater. These heaters are installed permanently. The most common installation location is on outside wall under the windows. They should be kept unobstructed because it operates on the method of natural circulation of heated air to distribute heat. These units are available in different dimensions and capacity to be suitable for the heating requirements of a specific area or room.

An 'electric-resistance' baseboard heater uses the resistivity of a wire for generating heat. These types of heaters consume a lot of electric energy. A pair of dedicated electric wire connects the heater to the electric supply board of the house with proper isolating and protecting devices. The installation cost and price of the units are the lowest among the other options but often has very high operating costs. 


\subsection{Electric Furnace}

An electric furnace produces heat by a number of heating elements/resistors to heat air which is distributed by a blower fan and a central ducting system.

An electric furnace draws return air from the ductwork then heats and distributes it through the supply ductwork. The operation is same as gas furnace or oil furnace. The heating element is a resistance coil or wire that converts electricity into heat when electricity passes

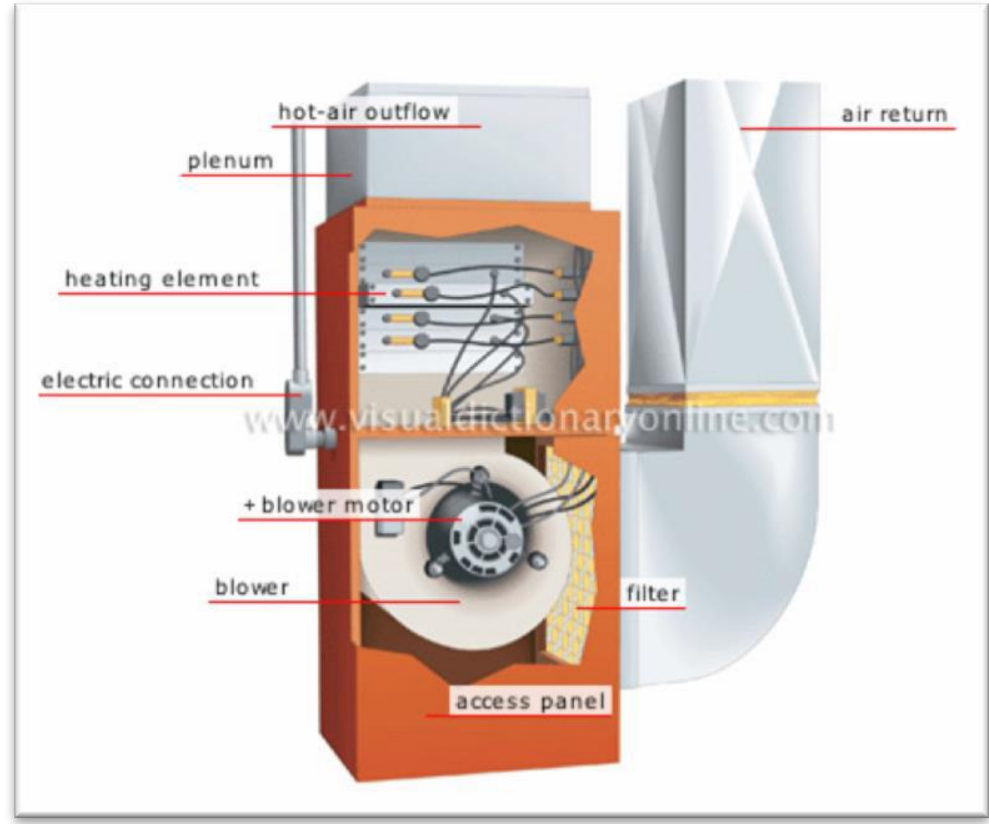

through it. The advantage of electric heating is that there is no exhaust or air supply needed. Electricity also powers the blower which draws the cooler air to the furnace for reheating and then pushed the air to the supply duct.

\subsection{Central Refrigeration Cooling system (Air Conditioner)}

A central air conditioner system is designed to lower the temperature of the entire house. It cools down the temperature which is named as sensible cooling as well as removes moisture which is named as latent cooling. The major component compressor and the condenser which is a heat exchanger coil remains outdoors and are connected by

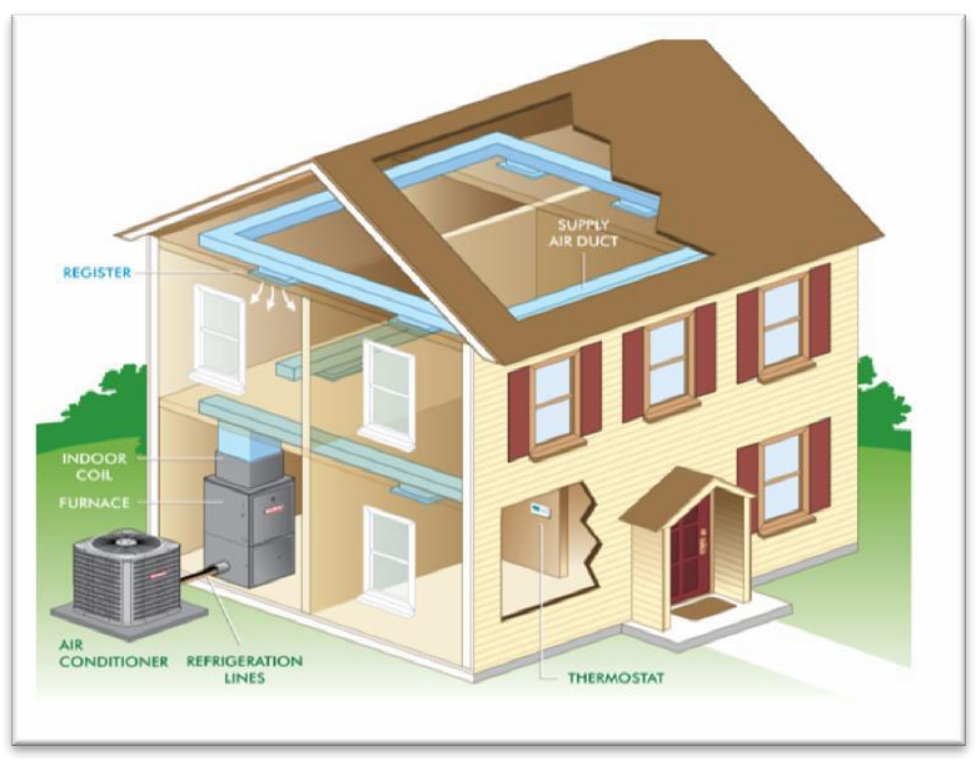


Copper pipes which are named as refrigerant lines to an indoor coil named evaporator mounted in the furnace. The same ducting system used for heating is used for cooling air distribution also.

A central air conditioner uses electrical energy to move heat from colder space to hotter space in other way it takes heat away. This is called refrigeration cycle which uses a compressor cycle to transfer heat from the house to the outdoors. The refrigeration cycle (or compressor cycle) uses a special refrigerant to move heat while uses electrical energy to drive the compressor. When the refrigerant changes its state from liquid to gas in the component named evaporator it absorbs heat from the inside of the house, after that the same refrigerant release heat when it changes from gas to liquid.

The compressor passes high pressure low temperature refrigerant through a device named expansion device, this valve changes the state of the liquid refrigerant to a low-pressure liquid/gas mixture. Then this mixture is passed through the indoor coil or evaporator, here in the evaporator the liquid part of the refrigerant absorbs heat from household air and becomes a saturated low-temperature vapor (gas).

The low-temperature vapor is compressed by a compressor that reduces its volume and results increase in its temperature. At the exit of the compressor it becomes a high-pressure, hightemperature vapor. This high pressure, high temperature vapor is passed to the outdoor coil or condenser where it rejects heat to the outdoor air. This heat rejection converts the refrigerant to a relatively low temperature liquid. The liquid refrigerant then returns to the expansion valve and the cycle is repeated.

As the hot room air passes over the indoor coil it cools down and moisture is removed by condensation. Condensation is collected in a pan at the bottom of the housing and passed to a drain. 


\subsection{The integrated heating/cooling system in the house}

Our proposed house is using a combined system of Electric Furnace and Refrigeration air conditioning. Both the heating and cooling systems use the same ductwork, air handling system, filter, blower, thermostat etc.

The combined system can do the job of heating, cooling, humidifying (a humidifier should be installed) and

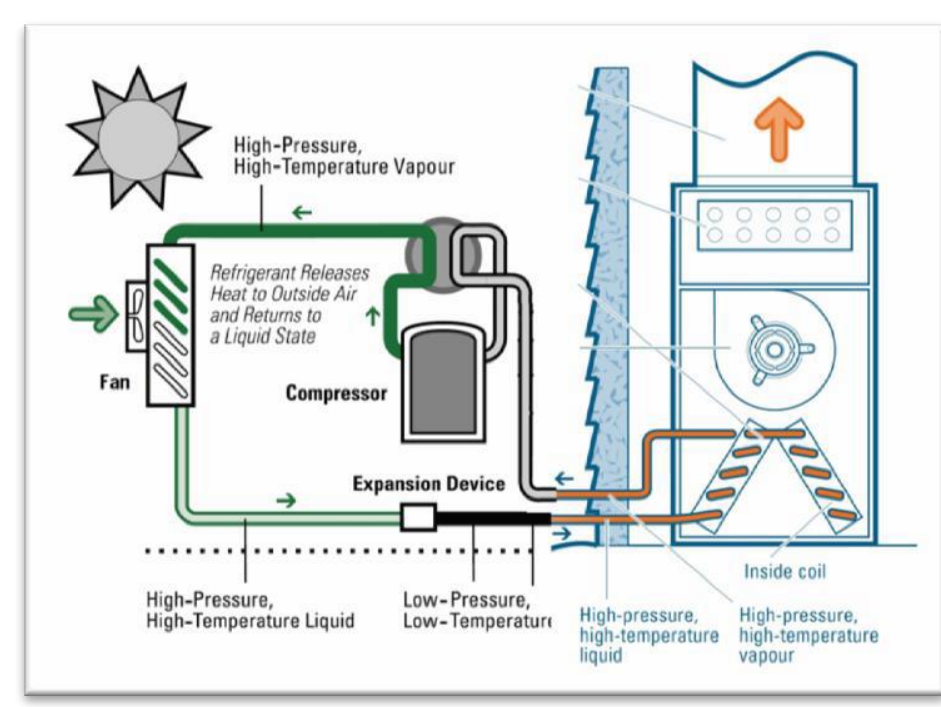
dehumidifying. The integrated system uses electrical energy for heating and cooling even to run the blower and control system.

The cooling system works in summer time whereas the heating system works in winter time. Both the system can operate simultaneously in the overlapping periods of season changing if required thus can give the maximum comfort.

\subsection{Domestic Hot Water system in the house}

Domestic Hot Water (DHW) is the second largest amount of energy consumer in a Canadian House. DHW requirement depends on the activities, lifestyle and number of occupants in the house. Depending on the season and the consumption of the occupants the Domestic Hot Water requirement could be as high as $20 \%$ of the total energy requirement of the house.

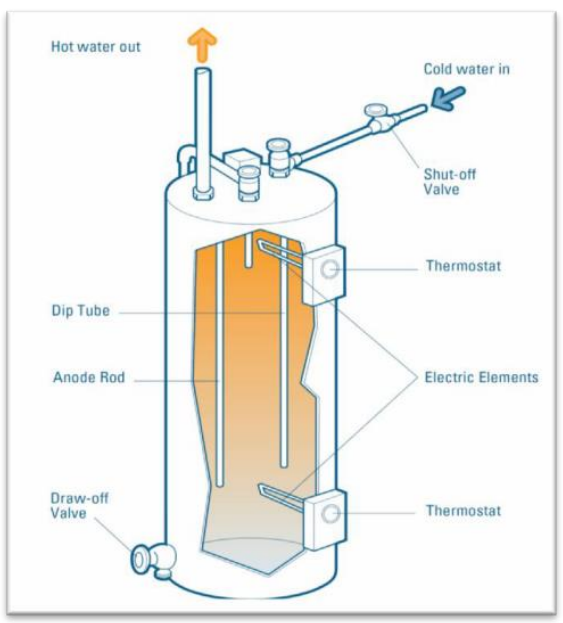


Our subject home is equipped with an electric water heater. An electric heater consists of a metal tank insulated inside and outside. There are two electric resistive elements which produce heat when electricity is passes through it. These elements are submerged into water. The whole system is controlled by thermostat and sensors.

When hot water is needed the sensor senses the requirement and activates the elements. The elements then heat the water up to the set temperature. Required water temperature is set by thermostat control.

\subsection{Lighting and Appliance Loads of the House}

Depending on the size of the residence and the occupant's nature of living the standard lighting, appliance, fan loads and exterior loads are considered. 


\subsection{The constrains}

To calculate the heating/cooling and DHW requirement the constrains are as follows:

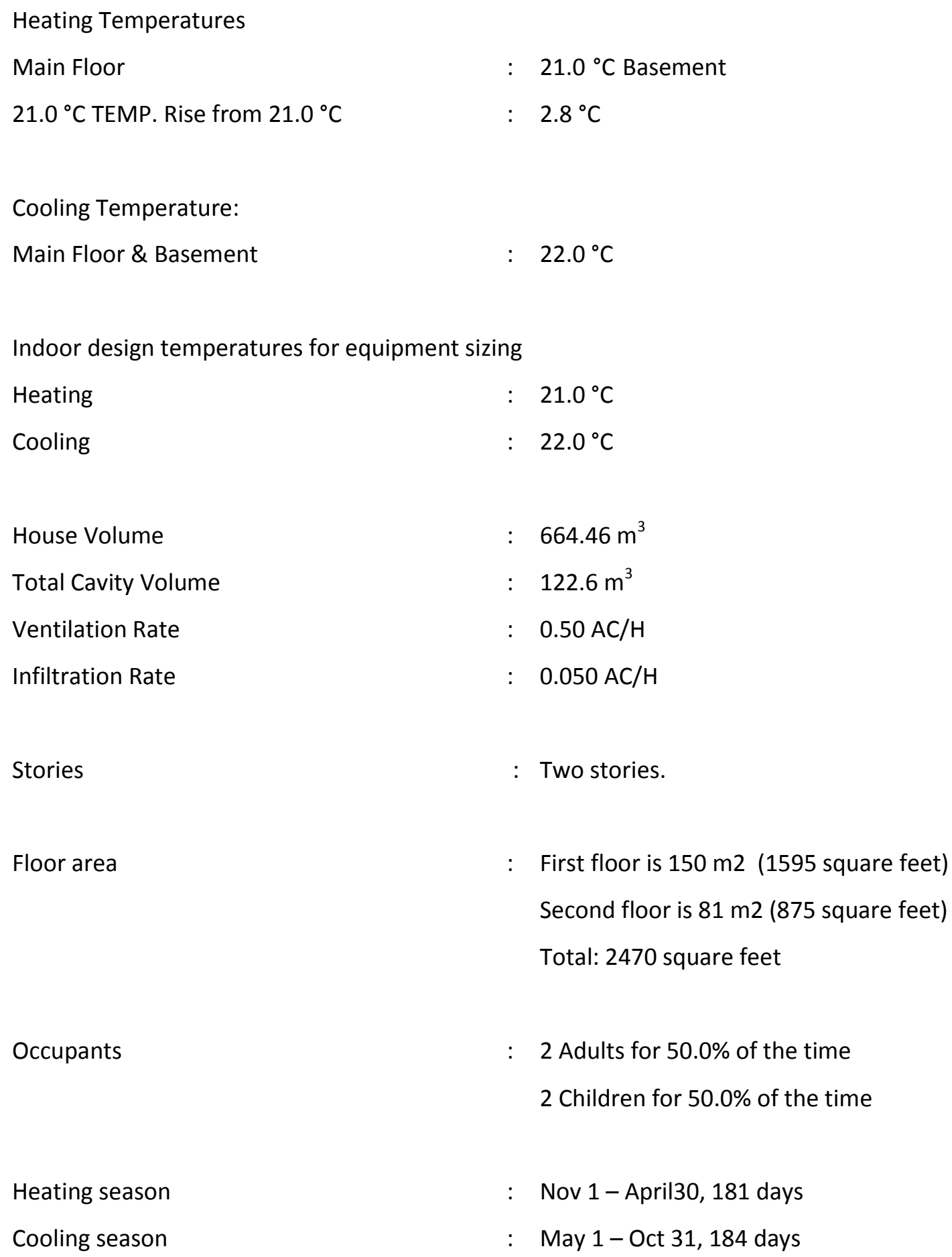

Floor area

: First floor is $150 \mathrm{~m} 2$ (1595 square feet) Second floor is $81 \mathrm{~m} 2$ (875 square feet) Total: 2470 square feet

Occupants

: 2 Adults for $50.0 \%$ of the time 2 Children for $50.0 \%$ of the time

Heating season

: Nov $1-$ April30, 181 days

Cooling season

: May $1-$ Oct 31, 184 days 


\subsection{The overall heat loss and Heating Energy Requirement}

The overall heat loss of a building is calculated as:

$\mathrm{H}=\mathrm{H}_{\mathrm{t}}+\mathrm{H}_{\mathrm{v}}+\mathrm{H}_{\mathrm{i}}$, where

$\mathrm{H}=$ overall heat loss $(\mathrm{W})$

$\mathrm{H}_{\mathrm{t}}=$ heat loss due to transmission through the envelope (W)

$H_{v}=$ heat loss caused by ventilation (W)

$\mathrm{H}_{\mathrm{i}}=$ heat loss caused by infiltration (W)

Now,

\section{Calculating Heat loss due to Transmission $\mathrm{H}_{\mathrm{t}}$ :}

The heat loss, or norm-heating load, through walls, windows, doors,

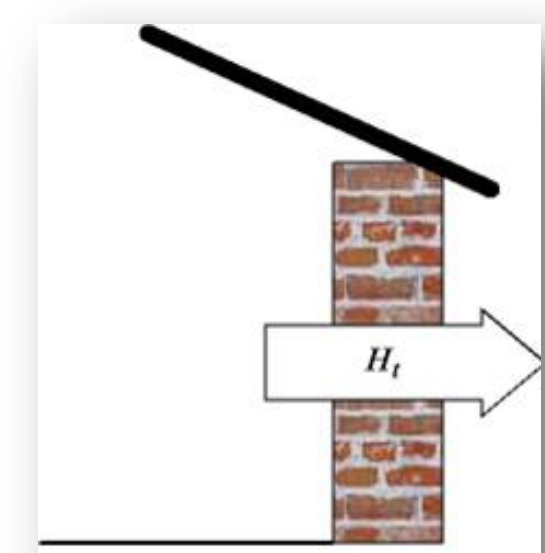

Heat Loss in Winter ceilings, floors etc. can be calculated as

$H_{t}=A \cup\left(t_{i}-t_{0}\right)$

where

$\mathrm{H}_{\mathrm{t}}=$ transmission heat loss $(\mathrm{W})$

$A=$ area of exposed surface $\left(\mathrm{m}^{2}\right)$

$\mathrm{U}=$ overall heat transmission coefficient $\left(\mathrm{W} / \mathrm{m}^{2} \mathrm{~K}\right)$

$t_{i}=$ inside air temperature $\left({ }^{\circ} \mathrm{C}\right)$

$\mathrm{t}_{\mathrm{o}}=$ outside air temperature $\left({ }^{\circ} \mathrm{C}\right)$

Heat loss through roofs should be added $15 \%$ extra because of radiation to space.

$H_{t, \text { roof }}=1.15 \mathrm{~A} \mathrm{U}\left(\mathrm{t}_{\mathrm{i}}-\mathrm{t}_{\mathrm{o}}\right)$

For walls and floors against earth should be modified with the earth temperature:

$H_{t}=A \cup\left(t_{i}-t_{e}\right)$, where

$\mathrm{t}_{\mathrm{e}}=$ earth temperature $\left({ }^{\circ} \mathrm{C}\right)$

The environment data for temperature was considered for finding out the average outdoor temperature throughout the heating season. Heating season was considered from November 1 to April 30. The outside temperature was higher than the design temperature of $21{ }^{\circ} \mathrm{C}$ for a negligible period of time (46.5 hours) within the heating season and was neglected. 
Calculated Average outdoor temperature, $t_{\mathrm{o}}$

Calculated average temperature difference, $\left(t_{i}-t_{0}\right)$
$=3.0560{ }^{\circ} \mathrm{C}$

$=18.1381^{\circ} \mathrm{C}$

UA factor for the building

$$
\begin{aligned}
& =\Sigma A U \\
& =U_{\text {wall }} A_{\text {wall }}+U_{\text {door }} A_{\text {door }}+U_{\text {window }} A_{\text {windows }}+U_{\text {floor }} A_{\text {floor }}+1.15 U_{\text {roof }} A_{\text {roof }}
\end{aligned}
$$

UA factor for the building was calculated using HOT 2000 software by inputting the data of the whole building envelope.

$\widehat{\mathrm{H} 2 \mathrm{X}} \mathrm{HOT} 2000$ - Baseboard heating final.HSE

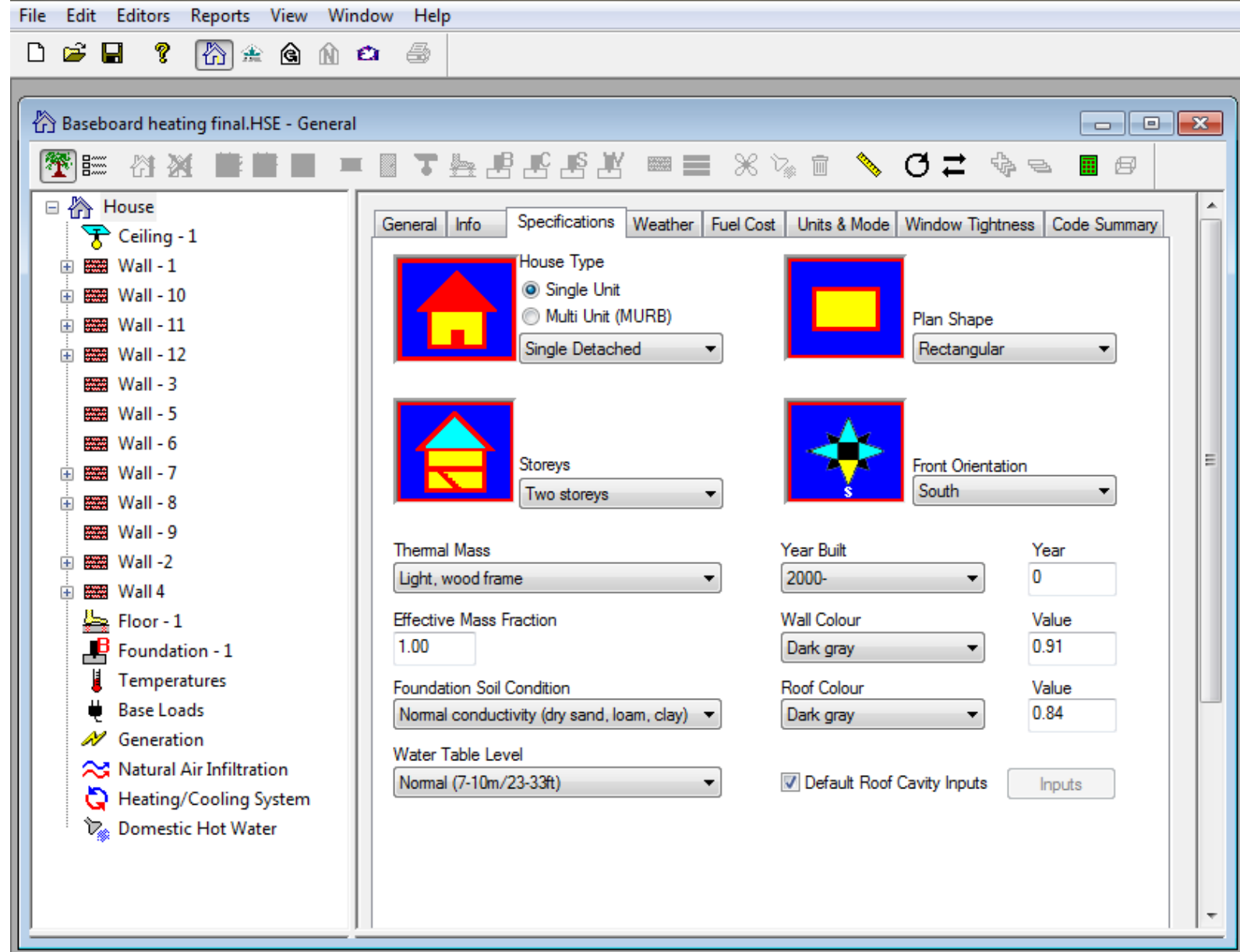

UA factor for the building

$=\Sigma A U$

$=U_{\text {wall }} A_{\text {wall }}+U_{\text {door }} A_{\text {door }}+U_{\text {window }} A_{\text {windows }}+U_{\text {floor }} A_{\text {floor }}+1.15 U_{\text {roof }} A_{\text {roof }}$

$=281.12 \mathrm{~W} /{ }^{\circ} \mathrm{C}$ 


$$
\begin{array}{ll}
\text { Power in Heat loss } & =281.12 \times 18.1381 \mathrm{~W} \\
& =5,098.98 \mathrm{~W} \\
& =181 \text { days } \\
& =181 \times 24 \times 3600 \text { seconds } \\
\text { Heating season } & =15,638,400 \text { Seconds } \\
\text { Transmission heat loss, } \mathbf{H}_{\mathbf{t}} \quad & =5,098.98 \mathrm{~W} \times 15,638,400 \text { Seconds } \\
& =79,739,912,118.87 \mathrm{~J} \\
& =\mathbf{7 9 , 7 3 9 . 9 1} \mathbf{M J}
\end{array}
$$

\section{Heat loss by ventilation}

The heat loss due to ventilation without heat recovery can be expressed as:

$$
\begin{aligned}
& H_{v}=c_{p} \rho q_{v}\left(t_{i}-t_{o}\right) \text {, where } \\
& H_{v}=\text { ventilation heat loss }(W) \\
& \text { Now, } \\
& c_{p}=\text { specific heat capacity of air }(\mathrm{kJ} / \mathrm{kg} \mathrm{K}) \\
& =1.005 \mathrm{~kJ} / \mathrm{kg} \mathrm{K} \\
& \rho=\text { density of air }\left(\mathrm{kg} / \mathrm{m}^{3}\right) \\
& =1.205 \mathrm{~kg} / \mathrm{m}^{3} \\
& \mathrm{q}_{\mathrm{v}} \quad=\text { air volume flow }\left(\mathrm{m}^{3} / \mathrm{s}\right) \\
& =664.46 \times .056 \mathrm{~m}^{3} / \mathrm{hr} \\
& =37.209 \mathrm{~m}^{3} / \mathrm{hr} \\
& =37.209 \times 181 \times 24 \mathrm{~m}^{3} / \text { heating season } \\
& =161,639.19 \mathrm{~m}^{3} / \text { heating season } \\
& \text { Ventillation Heat Loss, } \mathbf{H}_{v}=c_{p} \rho q_{v}\left(t_{i}-t_{o}\right) \\
& =1.005 \times 1.205 \times 161,639.19 \times 18.1381 \\
& =3,550,516.91 \mathrm{~kJ} \\
& =3,550.516 \mathrm{MJ}
\end{aligned}
$$

\section{Heat loss by infiltration}

Due to leakages in the building construction, opening and closing of windows, etc. the air in the building shifts. As a rule of thumb the number of air shifts is often set to 0.5 per hour. The value 
is hard to predict and depend of several variables - wind speed, difference between outside and inside temperatures, the quality of the building construction etc.

The heat loss caused by infiltration can be calculated as

$H_{i}=c_{p} \rho n V\left(t_{i}-t_{o}\right)$

Now,

$H_{i}=$ heat loss infiltration (W)

$\mathrm{c}_{\mathrm{p}} \quad=$ specific heat capacity of air $(\mathrm{kJ} / \mathrm{kg} \mathrm{K})$

$=1.005 \mathrm{~kJ} / \mathrm{kg} \mathrm{K}$

$\rho=$ density of air $\left(\mathrm{kg} / \mathrm{m}^{3}\right)$

$=1.205 \mathrm{~kg} / \mathrm{m}^{3}$

$\mathrm{n} \quad=$ number of air shifts in the heating season

$=.05 \times 181 \times 24$

$=217.2$

$\mathrm{V}=$ volume of room $\left(\mathrm{m}^{3}\right)$

$=664.46 \mathrm{~m}^{3}$

$\mathrm{t}_{\mathrm{i}} \quad=$ inside air temperature $\left({ }^{\circ} \mathrm{C}\right)$

$\mathrm{t}_{\mathrm{o}} \quad=$ outside air temperature $\left({ }^{\circ} \mathrm{C}\right)$

Infiltration Heat Loss, $\mathbf{H}_{\mathrm{i}} \quad=\mathrm{c}_{\mathrm{p}} \rho \mathrm{nV}\left(\mathrm{t}_{\mathrm{i}}-\mathrm{t}_{\mathrm{o}}\right)$

$=1.005 \times 1.205 \times 217.2 \times 664.46 \times 18.1381$

$=3,169.00 \mathrm{MJ}$

Now,

Overall Heat Loss, $\mathrm{H}$

$=\mathrm{H}_{\mathrm{t}}+\mathrm{H}_{\mathrm{v}}+\mathrm{H}_{\mathrm{i}}$

$=79,739.91+3,550.52+3,169.00$

$=86,459.43 \mathrm{MJ}$

Usable Internal Gains

$=\quad 23,055.49 \mathrm{MJ}$

Usable Solar Gains

$=\quad 4,283.87 \mathrm{MJ}$

Total Gains

$=\quad 27,339.36 \mathrm{MJ}$ 
Energy Provided By The Heating System

$$
\begin{aligned}
& =86,459.43 \mathrm{MJ}-27,339.36 \mathrm{MJ} \\
& =\mathbf{5 9 , 1 2 0 . 0 7} \mathrm{MJ}
\end{aligned}
$$

\subsection{Overall Heat Gain and Cooling Energy Requirement}

To find the design cooling load it is assumed that the design Sensible Heat Ratio is 0.769.

The overall heat gain of a building is calculated as:

$\mathrm{H}=\mathrm{H}_{\mathrm{t}}+\mathrm{H}_{\mathrm{v}}+\mathrm{H}_{\mathrm{i}}$, where

$\mathrm{H}=$ overall heat gain $(\mathrm{W})$

$\mathrm{H}_{\mathrm{t}}=$ heat gain due to transmission through walls, windows, doors, floors, roofs and more (W)

$\mathrm{H}_{\mathrm{v}}=$ cold air loss caused by ventilation (W)

$\mathrm{H}_{\mathrm{i}}=$ cold air loss caused by infiltration (W)

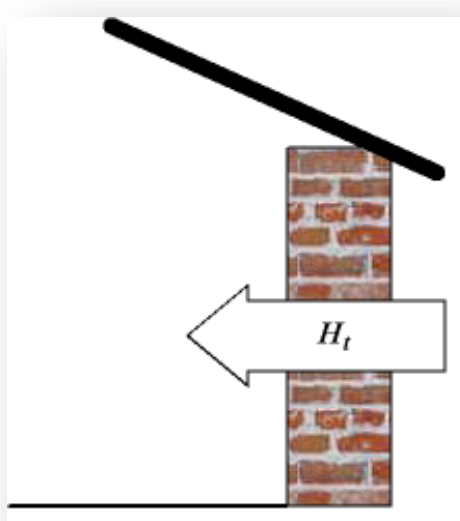

Heat Gain in Summer

$$
\begin{array}{ll}
\text { Calculated Average outdoor temperature, } \mathrm{t}_{\mathrm{o}} & =19.17{ }^{\circ} \mathrm{C} \\
\text { Calculated average temperature difference, }\left(\mathrm{t}_{\mathrm{o}}-\mathrm{t}_{\mathrm{i}}\right) & =(19.17-22)^{\circ} \mathrm{C} \\
& =-2.83{ }^{\circ} \mathrm{C}
\end{array}
$$

UA factor for the building $\quad=\Sigma A U$

Power in Heat gain

$$
=U_{\text {wall }} A_{\text {wall }}+U_{\text {door }} A_{\text {door }}+U_{\text {window }} A_{\text {windows }}+U_{\text {floor }} A_{\text {floor }}+1.15 U_{\text {roof }} A_{\text {roof }}
$$$$
=281.12 \mathrm{~W} /{ }^{\circ} \mathrm{C}
$$$$
=(-795.56) \mathrm{W}
$$

Heating season

$=181$ days

$=181 \times 24 \times 3600$ seconds

$=15,638,400$ Seconds

$\mathrm{H}_{\mathrm{t}}$

$=(-795.56) \mathrm{W} \times 15,638,400$ Seconds

$=-12,441.44 \mathrm{MJ}$ 


\section{Heat gain by ventilation}

The heat loss due to ventilation without heat recovery can be expressed as:

$$
\begin{aligned}
& \begin{aligned}
\mathrm{H}_{\mathrm{v}} \quad & =c_{p} \rho \mathrm{q}_{\mathrm{v}}\left(\mathrm{t}_{\mathrm{o}}-\mathrm{t}_{\mathrm{i}}\right) \\
& =1.005 \times 1.205 \times 161,639.19 \times(-2.83) \\
& =-553.969 \mathrm{MJ}
\end{aligned} \\
& \text { Heat gain by infiltration } \\
& \begin{aligned}
\mathrm{H}_{\mathrm{i}} \quad & \mathrm{c}_{\mathrm{p}} \rho \mathrm{nV}\left(\mathrm{t}_{\mathrm{o}}-\mathrm{t}_{\mathrm{i}}\right) \\
& =1.005 \times 1.205 \times 217.2 \times 664.46 \times(-2.83) \\
& =-494.616 \mathrm{MJ}
\end{aligned}
\end{aligned}
$$

Now,

The overall heat gain

$\mathrm{H}=\mathrm{H}_{\mathrm{t}}+\mathrm{H}_{\mathrm{v}}+\mathrm{H}_{\mathrm{i}}$

$=-12,441.44 \mathrm{MJ}-553.969 \mathrm{MJ}-494.616 \mathrm{MJ}$

$=-13,490.025 \mathrm{MJ}$

$\begin{array}{lll}\text { Usable Internal Gains } & = & 23,996.225 \mathrm{MJ} \\ \text { Usable Solar Gains } & = & 4,283.870 \mathrm{MJ} \\ \text { Total Gains } & = & \mathbf{2 8 2 8 0 . 0 9 5} \mathbf{M J}\end{array}$

Energy Removed By The Cooling System

$$
\begin{aligned}
& =-13,490.025 \mathrm{MJ}+28,280.095 \mathrm{MJ} \\
& =\mathbf{1 4 7 9 0 . 0 7} \mathrm{MJ}
\end{aligned}
$$

\subsection{Domestic Hot Water Requirement:}

Daily Hot Water Consumption = 225 Litres (assumed)

\subsection{Appliance Loads of the House}

Interior Lighting load connected and used is considered as $3 \mathrm{kwh} / \mathrm{day}$, Appliances as 14 $\mathrm{kwh} /$ day and other equipment as $3 \mathrm{kwh} /$ day, exterior load is considered as $4 \mathrm{kwh} / \mathrm{day}$. And such total calculated load is $24 \mathrm{kWh} /$ day. 


\subsection{Calculation of Energy Consumption of the Installed Systems}

Electric furnace or electric baseboard heaters use electric resistor to convert electricity into heat. There are no combustion losses or no fuel burning so the total electric energy is converted to heat. Typically we can consider the efficiency of the electric heater as $100 \%$. For this case in study it was considered an efficiency of $95 \%$ to be more conservative. The systems which burn fuels like gas, coal, oil, propane, wood might have several types of losses like transient operation, cold start, faulty combustion, exhaust loss etc. these losses determines the efficiency of the system. Steady state efficiency is measured after the furnace or boiler has stabled after start up. The furnace or boiler reaches its maximum efficiency when it reaches its maximum temperature after a prolonged running.

When the seasonal efficiency is measured it actually considers the performance of the equipment for the whole season it does not only consider the normal operating costs rather it considers the fact that very few times the equipment runs that enough to reach its steady state operation. In the period of mild weather at the changing time from summer to fall and spring to winter the efficiency is very low which impacts the seasonal efficiency. This efficiency is known as the Annual Fuel Utilization Efficiency (AFUE). This AFUE is the most useful tool to justify the performance of heating/cooling equipment. 


\subsection{Calculated Annual Energy Consumption by The Existing Systems:}

(Calculations are on Appendix B)

Annual Space Heating Energy Consumption $=17,729.64 \mathrm{kWh}$

Annual Space Cooling Energy Consumption $\quad=\quad 1,831.07$

$\mathrm{kWh}$

Annual DHW Heating Energy Consumption $=4,826.00$

$\mathrm{kWh}$ Annual Appliance Load Energy Consumption $=8,760.00$

kWh Total: $\quad=\quad 33,146.71$

kWh

Unit price of Electricity $\quad=\quad \$ 0.06 / \mathrm{kWh}$

Total Energy Cost $\quad=\quad \$ 1,988.80 /$ year

Greenhouse Gas Emissions = 14.80 tonnes/year

(calculated by the Software HOT 2000)

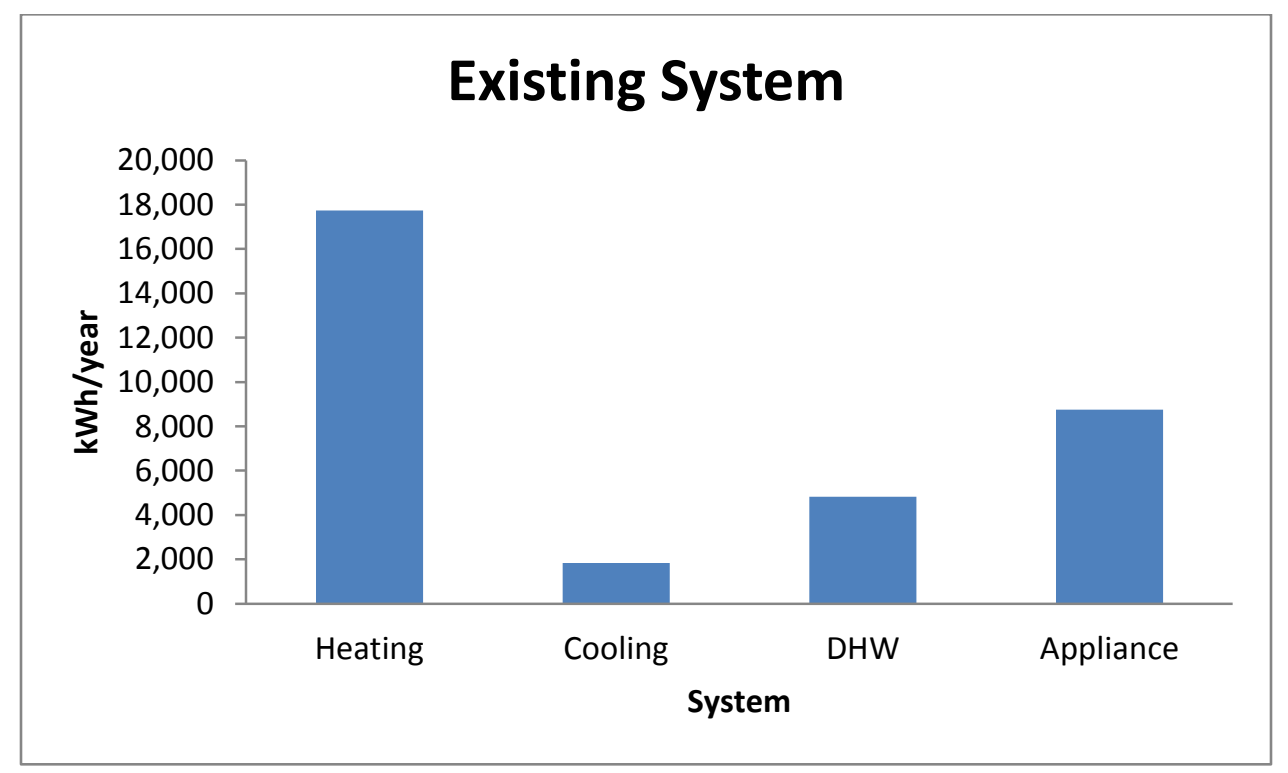




\subsection{The Four-Steps of Decision-Making Process For Energy Efficient Home}

The scope of this study is to Improve or modify the existing home heating, cooling, DHW and appliance system. The improvement should be financially and environmentally beneficial. In reality every household is located in different geological, economic and environmental surroundings. Every household has its own unique heating, cooling, DHW, lighting and appliance requirements and options. It needs study to understand which options are both available and will provide the optimal benefits for the specific situation. In this chapter, the five steps in the decision-making process for home energy improvement are described in detail to find out the right selection of heating, cooling, DHW and appliance.

\subsection{Step 1: Getting started}

As our house is with an existing Heating, Cooling, DHW and appliance system it is needed to conduct a ecoENERGY evaluation of your household. This ecoENERGY evaluation will create a detailed evaluation of the systems energy efficiency rating and will bring recommendations for improving the home's energy performance. This information will be very helpful to plan and execute the energy upgrades cost-effectively into renovation projects which will result a more comfortable home that is environmental friendly uses less energy.

\subsection{Step 2: Draftproofing and Insulating}

A new and improved system will not reduce the heating/cooling load remarkably if the house envelope has air leaks or needs more insulation. So the whole house should be closely inspected to have a close look at where the insulation and leak losses could be reduced by draftproofing and insulating before changing the heating/cooling system. A blower door is a machine used to measure the airtightness of buildings. It can also be used to measure airflow between building zones, to test ductwork airtightness and to help physically locate air leakage sites in the building envelope.

\subsection{Step 3: Selecting the energy source}

The next step is to select the available energy source for the modification. The options may 
include all available source of energy like propane fuel oil, natural gas and electricity. The available natural resources should also be checked like GeoExchange and air-source heat pumps. A mix of available conventional energy sources and renewable energy sources could be considered. Renewable energy includes solar, wind, biofuel etc. This document focuses on GeoExchange or Geothermal heat pump.

The other thing should be considered in selecting the energy source is environment. Each form of energy has a different environmental impact at various points in its cycle from production to use to after use residue; the impact could be spills and leaks during transportation, urban smog, acid rain and climate change. Every form of energy has some negative impact on the environment. Some has very negligible impact such as solar and wind. Energy use in the home could affect the environment in different ways, such as exhaust coming out of the chimney, emissions at an powerplant and flooding at hydroelectric electricity site. The two things could be done to minimize the environmental impact of the energy use at home are - Selecting the cleanest energy source available and the highest-efficiency equipment.

\subsection{Step 4: Selecting or improving the heat distribution system}

Most electric furnace heating systems are forced-air systems. There are few hydronic systems present which circulates water. All central air conditioning (heating/cooling) systems consist of a furnace or boiler, a central air handling unit (integrated with the furnace), a distribution network consisting of ducts and registers or pipes and radiators and a thermostat which controls and regulates the system.

The most common type of distribution system in a central heating system used in Canadian homes is forced air. This system has several advantages like ability to provide quick heat, air filtration, dehumidify and humidify the air. It can integrate fresh outside air and can facilitate air ventilation to a central air conditioning system. The air handling unit can provide air circulation on a year round basis because it is equipped with an efficient motor-fan set.

Geothermal heat pump has a low temperature energy source instead of high temperature 
source in case of an electric furnace. So the distribution system always needs to be modified. The duct cross section and the fan could be needed to increase by $30 \%$. 


\subsection{Proposed Alternate System 1 - Ground Source Heat Pump}

The proposed system is a ground Source heat pump (sometimes named earth-energy systems (EESs) also), considered instead of the combined electric furnace and compressor cooling system. The heating and cooling is done by Ground Source Heat Pump DHW is provided by the depurheater of the heatpump. Electric heater is there for supplementary heating of space and water.

\subsection{System description:}

What is a Heat Pump and How Does it Work?

A heat pump is an electrical device which does not produce any energy rather transfers energy from one place to another place. People are using heat pumps for decades. The most widely used form of heat pump is refrigerators

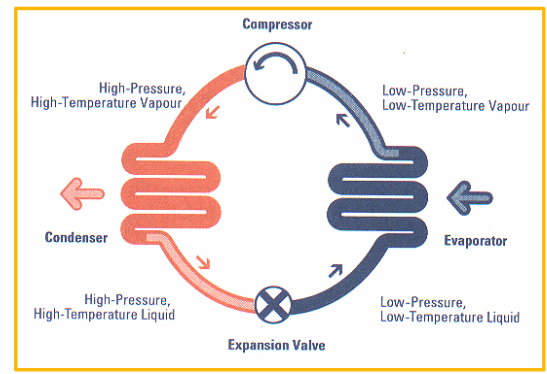
and air conditioners.

Heat pump circulates a refrigerant through two devices named evaporator and condenser and transfers heat between them. A device named compressor pumps the refrigerant between the evaporator and condenser coil. In the evaporator the refrigerant absorbs heat from the adjacent area while evaporates at low pressure. The refrigerant is sucked by the compressor and compressed to a higher pressure and temperature. Then it is delivered to the condenser where it releases heat to the surroundings. The heat released by the condenser is the summation of the heat absorbed in the evaporator and the energy entered to the compressor.
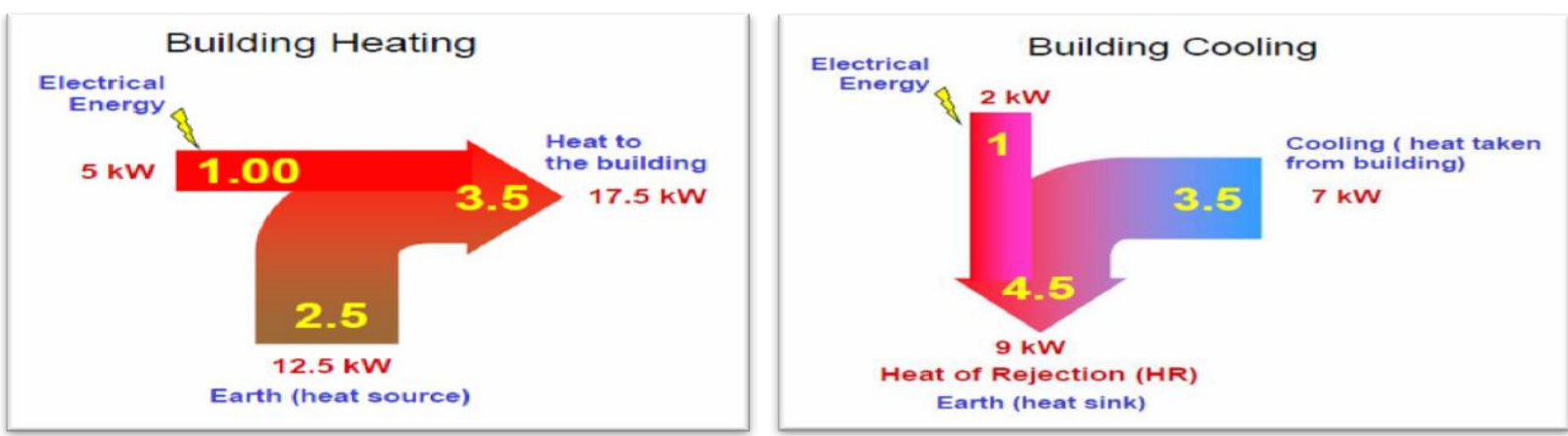
Refrigerators and air conditioners are two example of heat pump working in cooling mode. A refrigerator has its evaporator coil surrounding the chambers and the condenser coil is behind the refrigerator or on the bottom of the refrigerator. Heat is absorbed from the chambers and rejected at the back or bottom of the refrigerator. This is the way how the temperature inside the refrigerator is dropped. In the same way, an air conditioner absorbs heat from inside the building and releases it outside in the open air.

The heat pump can cycle the condenser and evaporator between themselves. When the heating is required the unit inside the building becomes the condenser and the unit outside becomes the evaporator. When cooling is required the unit inside the building becomes the evaporator and the outside unit becomes the condenser. Thus the heat pump can provide heating and cooling round the year. Heat pump can heat up the building even when the outside temperature is as low as $-18^{\circ} \mathrm{C}$.

An air source heat pump uses the outside air as the source and sink of heat. It absorbs heat from outside air in the winter and rejects heat in the summer. The coefficient of performance (COP) of the heat pump depends on the temperature difference between the inside and outside of the house.

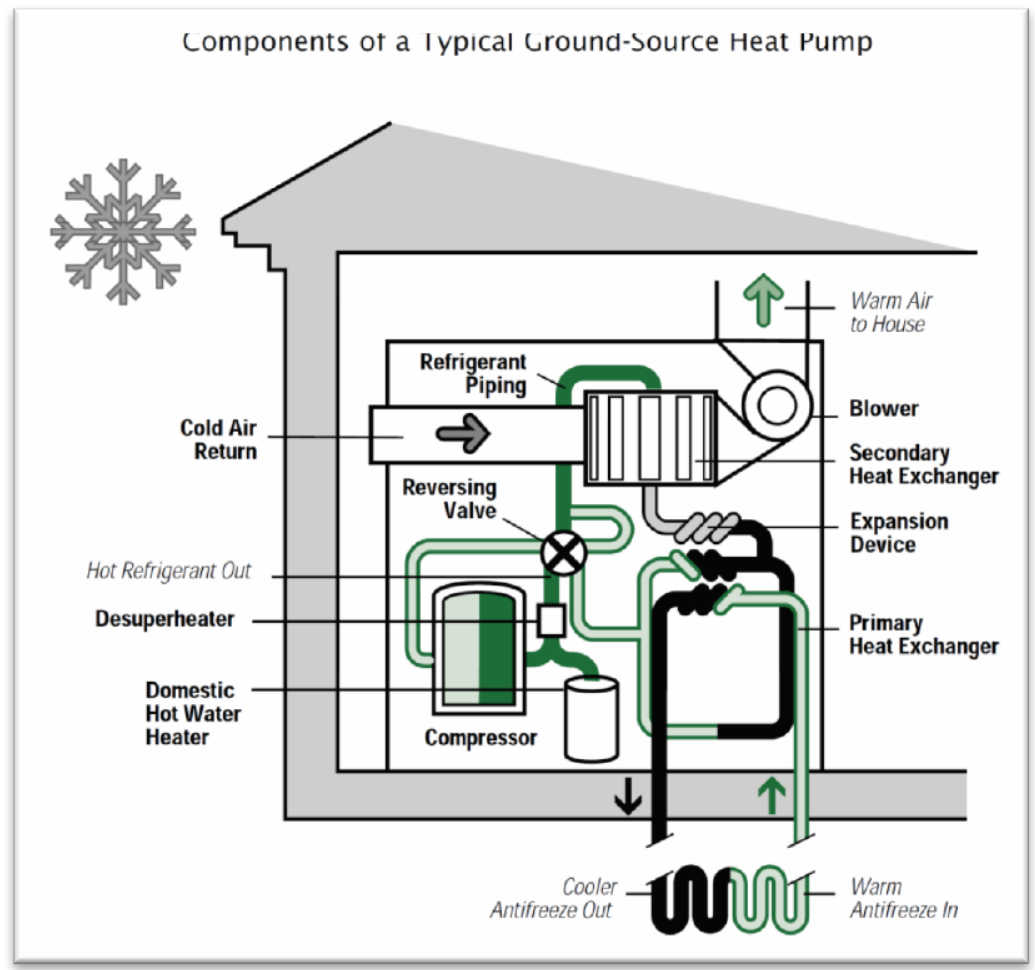


The ground source heat pump is the heat pump where ground or ground water is used as the heat source or heat sink. Ground source heat pump is more efficient than that of air source.

\subsection{Operating principle of GLHP:}

GLHP has three basic parts:

Heat pump - in the mechanical room

Ground Loop - in the ground Distribution System - inside the Building

\section{Heat Pump:}

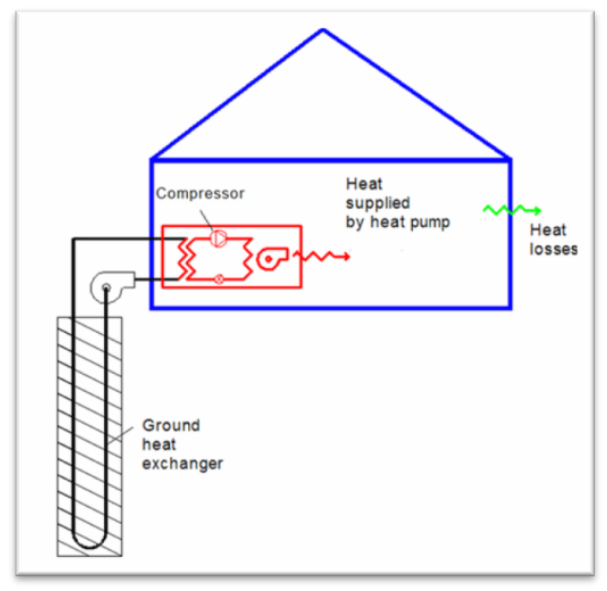

Heat pump is the main driver of the system. It consists an electrically driven compressor which circulates the refrigerant in a cycle through evaporator, compressor, condenser and expansion valve. The refrigerant absorbs heat from the surroundings in the evaporator and converts to gas. The pressure inside the evaporator is low. This gas is then compressed and the final state exiting from the compressor is high pressure high temperature. Then the refrigerant is passed through the condenser where it releases the heat to the surroundings. 


\subsection{Design Condition}

The behavior of the coupled GSHP-Building system is relatively complex and is time and temperature dependent. Trying to capture these dependencies for the purpose of detailed design often requires a dynamic model using relatively short time steps, which is not necessary at the preliminary feasibility stages of a project. Therefore, a simplified approach was investigated, which uses outside temperature as the critical variable.

An arrangement of pipe in a distinct pattern under the ground is the ground loop. This outdoor piping system could be either an open system or a closed loop. An open system exchanges heat with a body of water underneath the ground or ground surface. The water is drawn from a pond, lake or well directly to the heat pump for extraction. The water is discharged either to an above-ground body of water, such as a stream or pond, or back to the same underground water body through a separate well.

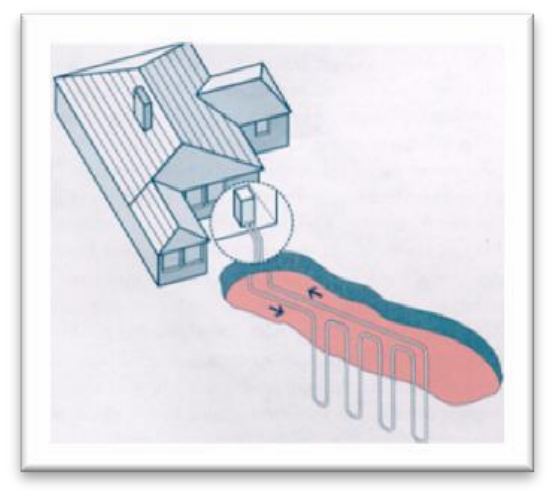

Closed-loop systems utilize a loop of piping buried under the ground or sunk in the lake/pond. An antifreeze solution (or refrigerant in the case of a DX earth-energy system), which has been chilled by the heat pump's refrigeration system to several degrees colder than the outside soil, circulates through the piping and absorbs heat from the surrounding soil. Our system is using Vertical ground loop buried vertically under the ground.

The horizontal arrangement is more common in rural areas, where properties are larger. The pipe is placed in trenches normally 1.0 to $1.8 \mathrm{~m} \mathrm{(} 3$ to $6 \mathrm{ft}$.) deep, depending on the number of pipes in a trench. Generally, 120 to $180 \mathrm{~m}$ (400 to $600 \mathrm{ft}$.) of pipe are required per ton of heat pump capacity. For example, a well-insulated, $185 \mathrm{~m}^{2}$ (2000 sq. ft.) home would

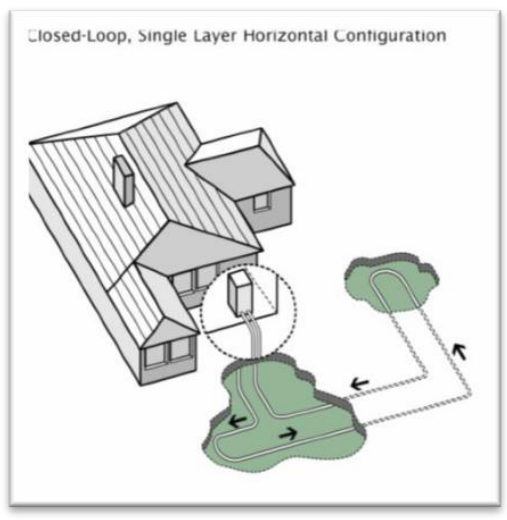
probably need a three ton system with 360 to $540 \mathrm{~m}$ (1200 to $1800 \mathrm{ft}$.) of pipe. 
A vertical closed-loop arrangement is an appropriate choice for most suburban homes, where lot space is restricted. Piping is inserted into bored holes that are $150 \mathrm{~mm}$ (6 in.) in diameter, to a depth of 18 to $60 \mathrm{~m}$ (60 to $200 \mathrm{ft}$.), depending on soil conditions and the size of the system. Usually, about 80 to $110 \mathrm{~m}$ (270 to $350 \mathrm{ft}$.) of piping is needed for every ton ( $3.5 \mathrm{~kW}$ or 12000 $\mathrm{Btu} / \mathrm{h}$ ) of heat pump capacity. U-shaped loops of pipe are inserted in the holes. DX systems can have smaller diameter holes, which can lower drilling costs.

\subsection{Installation Considerations}

GLHP or EESs must be carefully designed and professionally installed by qualified/certified contractors. While installing a GLHP the manufacturer's instruction must be followed. According to the code all installations should meet the requirements of CSA C448, an installation standard set by the Canadian Standards Association. Total cost of EESs/GLHPs varies according to the site specific condition. GLHP could be twice costly than the gas or electric furnace. The total cost for

ground water system could be cheaper than vertical or horizontal earth loop system which requires boring or trenching.

Irrespective of open or closed-loop, ductwork must be installed to circulate air in homes. The difficulty and complexity of installing ductwork will vary and should be assessed by a contractor. Installation cost may vary depending on the soil condition, pipe type, antifreeze solution, local laws etc. To be an attractive investment the capital should be returned in 5 years through energy cost savings.

\subsection{Major Benefits of Earth-Energy Systems}

- $\quad$ Quickly growing market - $88 \%$ in 2 years (NRCan)

- Environmental solution

- $\quad$ Financially viable

- $\quad$ Rapidly rising and unstable energy costs motivate the market

- $\quad$ Financial initiatives exist federally and in many provinces

- $\quad$ There's money to be made in the work itself! 
- $\quad$ GeotThermal is a renewable mature and competitive technology.

- $\quad$ Energy savings usually range between $200 \%$ and $400 \%$.

- Potential consumer savings in the millions; energy distribution companies may save billions in reducing peak demand and seasonal fluctuations.

- Combination of complementary technologies (e.g. passive \& active solar, highefficiency building techniques) adds even greater lifecycle value to investments.

\subsection{Operating Costs}

The operating costs of a GLHP system are probably very low comparing to those of other heating systems. This system saves fuel. The designer can find out how much money an earthenergy system would use and how much it will save.

However, the relative savings by GLHP will depend on whether the house is currently using electricity, natural gas or fuel oil. The operation of the GLHP is completely electrical, so it involves more electric energy. If the house is in an area where electricity is costly then the operation cost will be higher. The payback period of an investment in a GLHP system may be anywhere up to a decade or more.

\subsection{Factors Affecting Heating Cost Comparisons}

As stated earlier, the relative savings from an installed GLHP system can be expected from running the heat pump to provide heating in the home depend on a number of factors, including:

- $\quad$ Electricity cost and other fuels in the area.

- Where the home is located - severity of winter climate.

- The type and the efficiency of the heat pump under consideration.

- How the heat pump is sized or matched to the home - the balance point below which supplementary heating is required. 


\subsection{Supplementary Heating Systems}

Most GLHP system requires a supplementary heating system. The design load for the Heatpump is not the highest possible load rather it's about $70-90 \%$ of the maximum load. It saves money and comfort zone is increased. In the worst days the supplementary heating system will come to operation to keep the heat. An electric heater is ideal supplementary heating source. 


\subsection{Ground Source Heatpump System Mathematical Model:}

The soil temperature at a given depth will vary depending on the soil type, moisture content, etc. The following table which is provided, courtesy of the Ontario Ministry of the Environment, can be used as an approximate guide to determine soil temperature. Refer to the map below to obtain the freezing index degree days for the location being studied, then plot to obtain the approximate soil temperature at a given depth.
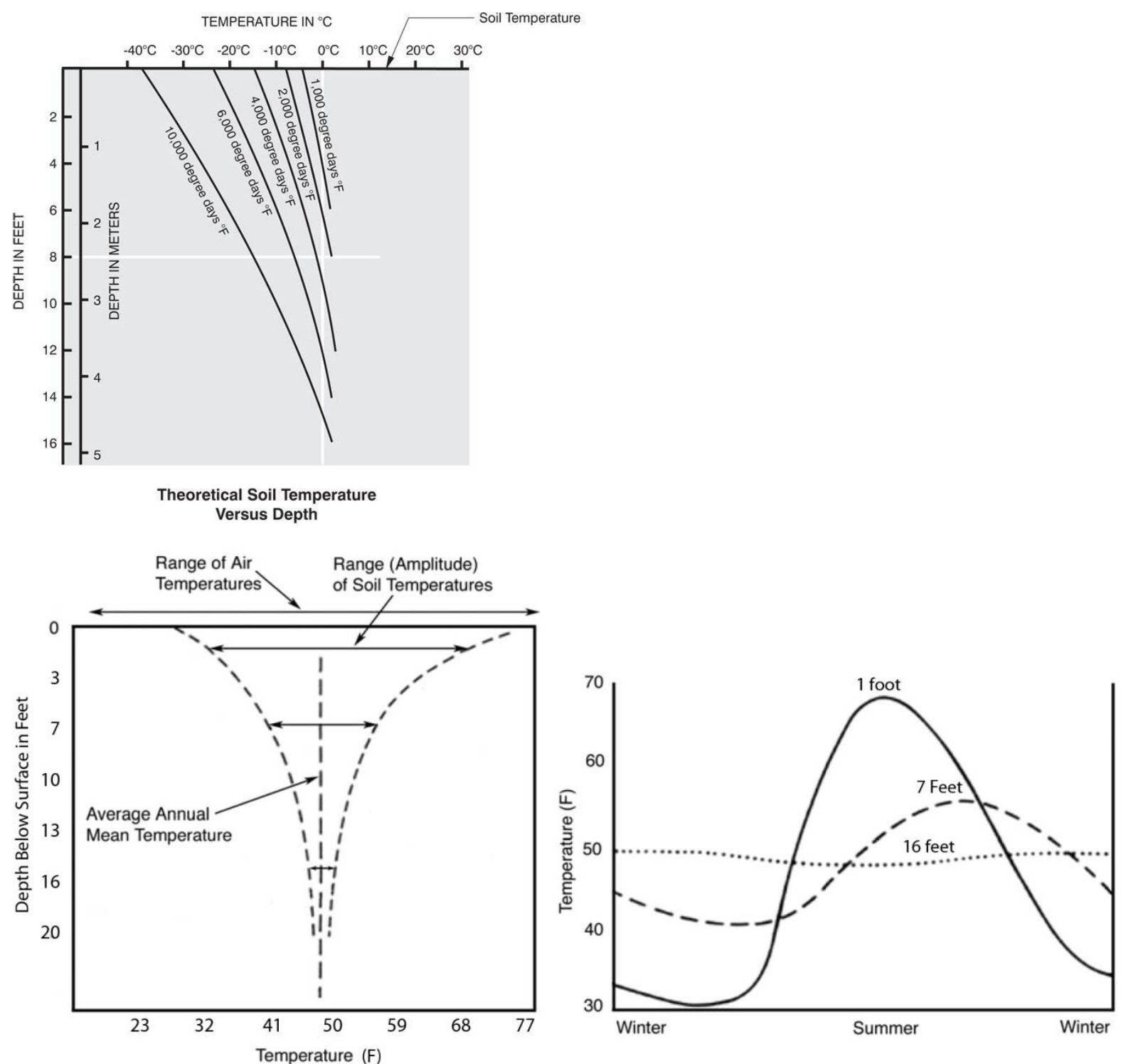

Depth dependence of ground temperatures (modified from Hanova \& Dowlatabadi, 2007) Source: RETScreen, NR Canada. 


\section{Ground Source Heat Pump Temperatures}

Ground temperature fluctuates according to ambient temperatures upto a depth of $15 \mathrm{~m}$. At the depth of $15 \mathrm{~m}$ the ground temperature remains almost stable equal to the annual average ambient temperature. The ground temperature increases irrespective of the season with the depth after $15 \mathrm{~m}$. This rate of increase in temperature is named as "Geothermal Gradient". The geothermal gradient is approximately $2^{\circ} \mathrm{C}$ per $100 \mathrm{~m}\left(1^{\circ} \mathrm{F}\right.$ per $\left.100 \mathrm{ft}\right)$. At a depth of 50 feet, the Earth temperature is approximately equal to the average annual temperature of ambient air.

Our proposed system is a vertical ground Source with a depth of 250 feet. For Toronto the annual average temperature was calculated as: $11.2^{\circ} \mathrm{C}$.

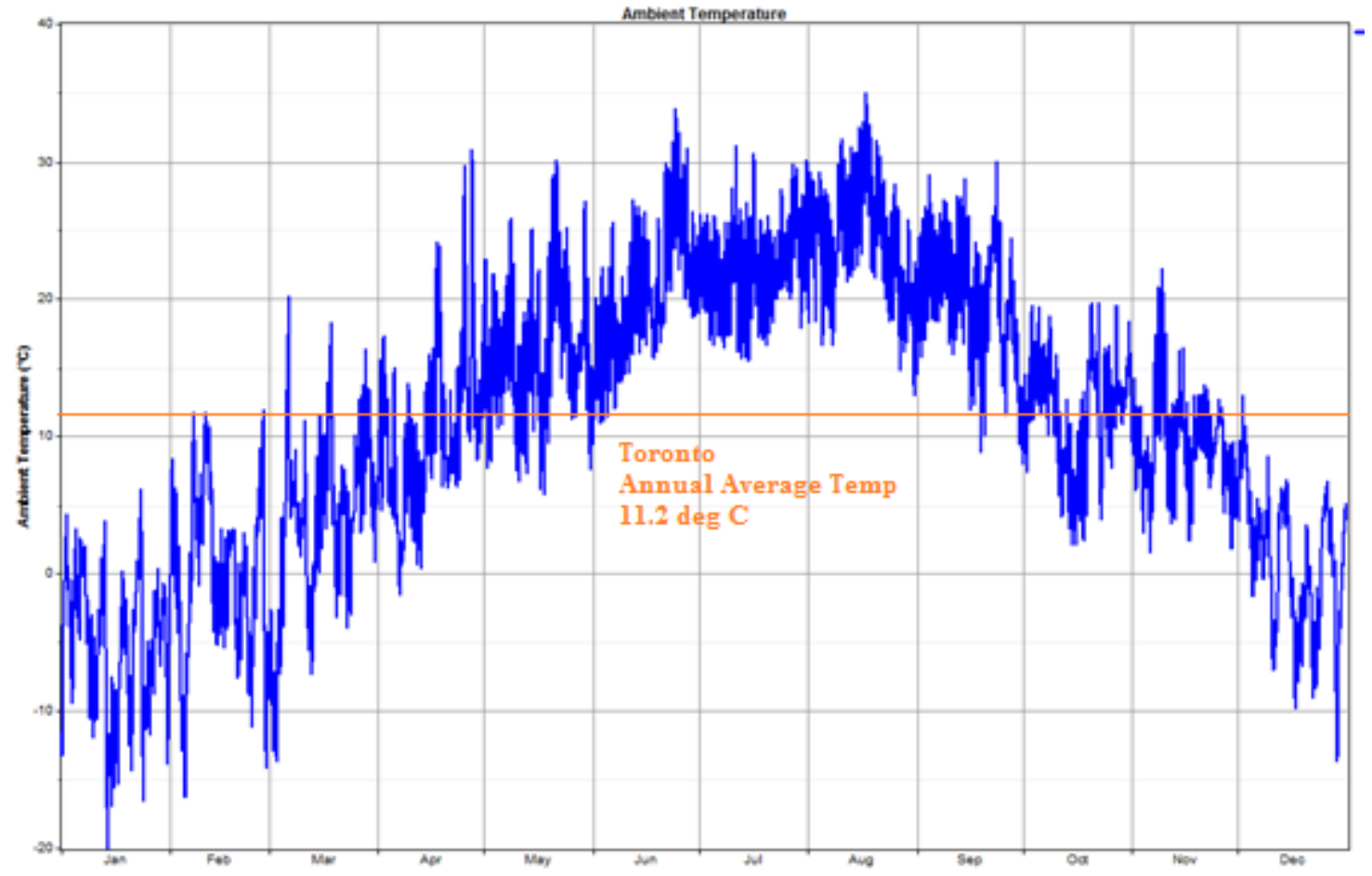




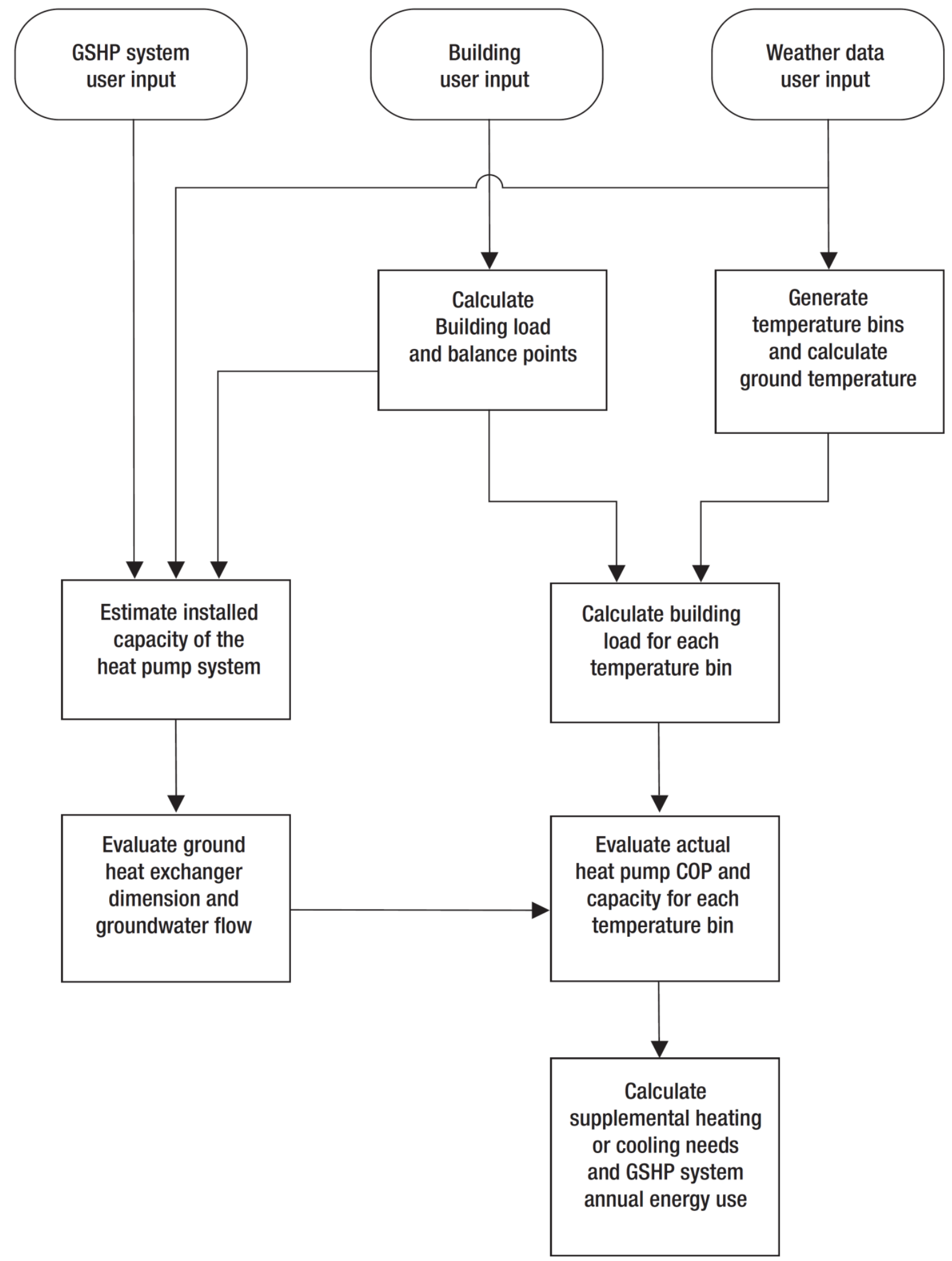

Ground-Source Heat Pump Energy Model Flowchart (Source: RETScreen). 
The ground temperature, $\mathrm{Tg}$, expressed in ${ }^{\circ} \mathrm{F}$, can be calculated using:

$$
T_{g}\left(X_{s}, t\right)=\overline{T_{g}}-A_{s} \exp \left(-X_{s} \sqrt{\frac{\pi}{365 \alpha}}\right) \cos \left(\frac{2 \pi}{365}\left[t-t_{o}-\frac{X_{s}}{2} \sqrt{\frac{365}{\pi \alpha}}\right]\right)
$$

where $X_{s}$ is the soil depth in feet, $t$ is the day of year, $\mathrm{Tg}$ is the mean annual surface soil temperature, As is the annual surface temperature amplitude (TTmaxmin), $\alpha$ is the soil thermal diffusivity, and $t_{o}$ is a phase constant expressed in days.

The minimum and maximum ground temperatures for any depth can be expressed as:

$$
\begin{aligned}
& T_{g, \text { min }}=\overline{T_{g}}-A_{s} \exp \left(-X_{s} \sqrt{\frac{\pi}{365 \alpha}}\right) \\
& T_{g, \text { max }}=\bar{T}_{g}+A_{s} \exp \left(-X_{s} \sqrt{\frac{\pi}{365 \alpha}}\right)
\end{aligned}
$$

Total heat requirement is calculated as:

$$
\begin{gathered}
q_{\text {tot }, \text { heat }}=\sum_{i=1}^{p}\left(c_{0}+c_{1} T_{o, i}\right) h\left(T_{o, i}\right) \\
c_{o}=\left[\frac{q_{d, \text { heat }} \sum_{i=1}^{p} T_{o, i} h\left(T_{o, i}\right)-q_{\text {tot }} T_{d, \text { heat }}}{\sum_{i=1}^{p} T_{o, i} h\left(T_{o, i}\right)-T_{d, \text { heat }} \sum_{i=1}^{p} h\left(T_{o, i}\right)}\right] \\
c_{1}=\left[\frac{q_{\text {tot }}-q_{d, \text { heat }} \sum_{i=1}^{p} h\left(T_{o, i}\right)}{\sum_{i=1}^{p} T_{o, i} h\left(T_{o, i}\right)-T_{d, \text { heat }} \sum_{i=1}^{p} h\left(T_{o, i}\right)}\right]
\end{gathered}
$$

The length of Ground Heat Exchanger for heating, $L_{h}$, is

$$
L_{h}=q_{d, \text { heat }}\left[\frac{\frac{\left(C O P_{h}-1\right)}{C O P_{h}}\left(R_{p}+R_{s} F_{h}\right)}{T_{g, \text { min }}-T_{\text {ewt } \text { min }}}\right]
$$


The length of Ground Heat Exchanger for cooling, $L_{c}$, is

$$
L_{c}=q_{d, \text { cool }}\left[\frac{\frac{\left(C O P_{c}+1\right)}{C O P_{c}}\left(R_{p}+R_{s} F_{c}\right)}{T_{e w t, \max }-T_{g, \max }}\right]
$$

Coefficient of performance (COP) and Cooling / Heating Capacity $\left(\mathrm{Q}_{c / h}\right)$ :

The coefficient of performance (COP) of a heat pump system is a function of the entering water temperature. The model used in the RETScreen for GSHP Project is taken as the model in this study. For any GSHP the relation between the COP and the HP entering water temperature was first proposed by Tarnawski (1990).

The GSHP's heating or cooling load and the load to the ground heat exchanger are linked by the following equations:

For Heating:

$Q_{h}=Q_{h e, h} \frac{C O P_{h}}{C O P_{h}-1}$

For Cooling:

$$
Q_{c}=Q_{h e, c} \frac{C O P_{c}}{C O P_{c}+1}
$$

Where:

$\mathrm{Q}_{c}$ is the heat pump cooling capacity,

$\mathrm{Q}_{\text {he,c }}$ is the heat rejected to the $\mathrm{GHX}$ in cooling mode,

$\mathrm{Q}_{\mathrm{h}}$ is the heat pump heating capacity, and

$Q_{h e, h}$ is the heat extracted from the GHX in heating mode.

The method used to model the COP and the capacity as a function of the entering fluid 
temperature uses a quadratic polynomial correlation:

$C O P_{\text {actual }}=C O P_{\text {baseline }}\left(k_{0}+k_{1} T_{\text {ewt }}+k_{2} T_{e w t}^{2}\right)$

$Q_{c / h}=\chi\left(\lambda_{0}+\lambda_{1} T_{e w t}+\lambda_{2} T_{e w t}^{2}\right)$

where $\mathrm{COP}_{\text {actual }}$ is the actual COP of the heat pump, COP baseline is the nominal COP of the heat pump (entering water temperature is considered as $0^{\circ} \mathrm{C}$ for heating and $25^{\circ} \mathrm{C}$ for cooling), $\mathrm{Q}_{\mathrm{c} / \mathrm{h}}$ is the capacity of the heat pump for cooling or heating, and $\mathrm{ki}$ and $\lambda \mathrm{i}$ are correlation coefficients listed in the following table. Finally, $\chi$ is a capacity multiplier, calculated so that the system meets either the building's heating or cooling load.

Correlation coefficients Table:

\begin{tabular}{|c|c|c|c|}
\hline \multicolumn{2}{|c|}{ Correlation Coefficients } & Cooling & Heating \\
\hline \multirow{4}{*}{ COP } & $k_{0}$ & $1.53105836 \mathrm{E}+00$ & $1.00000000 \mathrm{E}+00$ \\
\cline { 2 - 4 } & $k_{l}$ & $-2.29609500 \mathrm{E}-02$ & $1.55970900 \mathrm{E}-02$ \\
\cline { 2 - 4 } & $k_{2}$ & $6.87440000 \mathrm{E}-05$ & $-1.59310000 \mathrm{E}-04$ \\
\hline \multirow{4}{*}{ Capacity } & $\lambda_{0}$ & $1.41186164 \mathrm{E}+00$ & $6.67872140 \mathrm{E}-01$ \\
\cline { 2 - 4 } & $\lambda_{1}$ & $-2.56202000 \mathrm{E}-03$ & $2.79889800 \mathrm{E}-02$ \\
\cline { 2 - 4 } & $\lambda_{2}$ & $-7.24820000 \mathrm{E}-05$ & $-1.06360000 \mathrm{E}-04$ \\
\hline
\end{tabular}

Quadratic Polynomial Correlation Coefficients Used in equations (70) and (71).

Source: RET Screen, Natural Resource Canada.

Either heating or cooling need should be considered as the design criteria. The design load is the dominating load between heating and cooling load round the year. If cooling is dominating then the capacity multiplier is: 


$$
\chi=\frac{q_{d, \text { cool }}}{\lambda_{0}+\lambda_{1} T_{\text {ewt, } \max }+\lambda_{2} T_{\text {ewt, } \max }^{2}}
$$

If heating load is dominant then the capacity multiplier is:

$$
\chi=\frac{q_{d, \text { heat }}}{\lambda_{0}+\lambda_{1} T_{\text {ewt, } \min }+\lambda_{2} T_{\text {ewt } \text { min }}^{2}}
$$

where $T_{\text {ewt,max }}$ is the maximum entering water temperature in cooling mode (summer) and $\mathrm{T}_{\text {ewt,min }}$ is the minimum entering water temperature in heating mode (winter).

For a given outdoor air temperature $T_{b i n, i}$, the entering water temperature $T_{w, i}$ is:

$$
T_{w, i}=T_{\text {min }}+\left(\frac{T_{e w t, \max }-T_{e w t, \min }}{T_{d, \text { cool }}-T_{d, \text { heat }}}\right)\left(T_{b i n, i}-T_{d, \text { heat }}\right)
$$

The graphical presentation of the relation between outdoor temperature and entering water temperature is shown below:

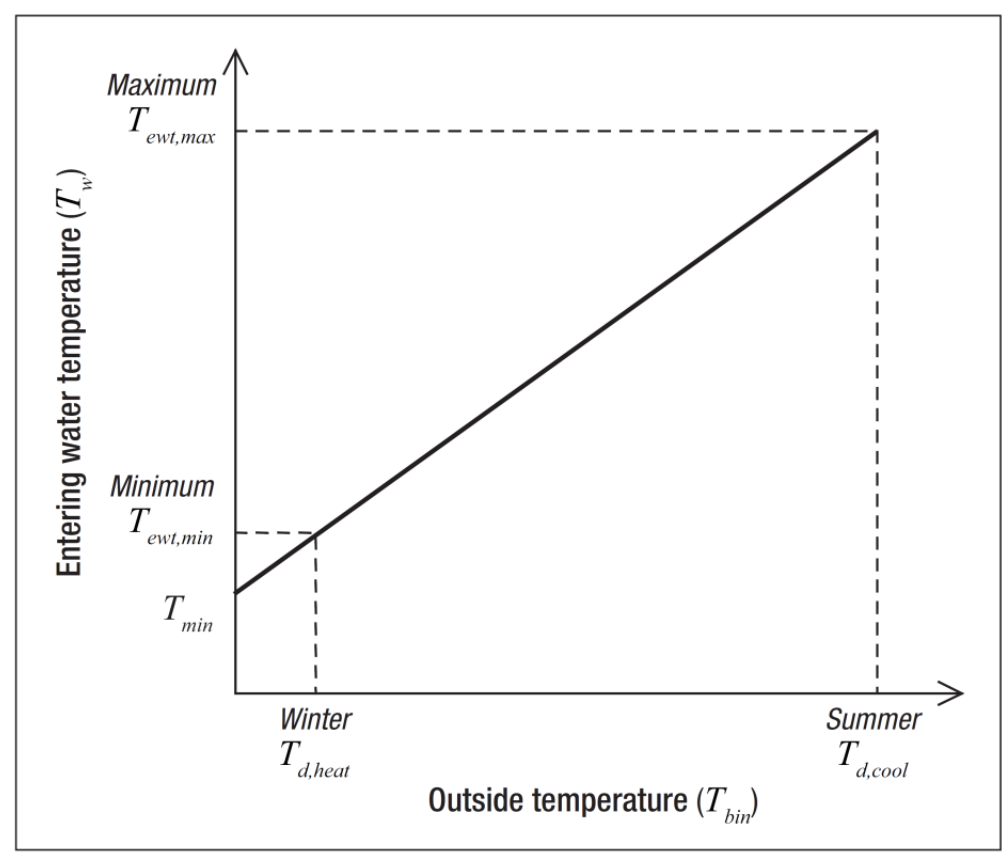

The ewt of the heatpump was considered as follows with respect to the ground temperature in 
modelling the GSHP:

- Minimum design entering water temperature:

$$
T_{e w t, \min }=T_{g, \min }-15^{\circ} \mathrm{F}
$$

- Maximum design entering water temperature:

$$
T_{e w t, \max }=\min \left(T_{g, \max }+20^{\circ} \mathrm{F}, 110^{\circ} \mathrm{F}\right)
$$

Actual COP was considered for the calculation of the load for the building. The electric energy needed is related by the following equation:

$C O P_{\text {actual }, h}=$ Heating Energy, $\mathrm{Q}_{\mathrm{h}} /$ System Input Energy

$C O P_{\text {actual }, c}=$ Cooling Energy, $\mathrm{Q}_{c} /$ System Input Energy

Heating System Input Energy = Heating Energy, $\mathrm{Q}_{\mathrm{h}} /$ COP actual, $h$

Cooling System Input Energy = Cooling Energy, $\mathrm{Q}_{c} / \mathrm{COP}_{\text {actual }, c}$

Heat extracted in winter, $Q_{h e, h}=Q_{h} \times\left(1-\frac{1}{\operatorname{COP}_{h}}\right) \times E F L H_{h}$

Heat rejected in summer, $Q_{h e, c}=Q_{c} \times\left(1+\frac{1}{\operatorname{COP}_{C}}\right) \times E F L H_{c}$

Heat Imbalance in the year,

$Q_{\text {Imbalance }}=Q_{c} \times\left(1+\frac{1}{\operatorname{COP}_{C}}\right) \times E F L H_{c}-Q_{h} \times\left(1-\frac{1}{\operatorname{COP}_{h}}\right) \times E F L H_{h}$

Where, $E F L H_{h}$ and $E F L H_{c}$ is the effective full load hours of heating and cooling respectively.

\subsection{Numerical Simulation and Performance Analysis:}

Based on the above mentioned model and the constrains of the system, the numerical simulation was performed by the use of a simulation software TRN Build 2.0, a data backup system was supported by a programmed MS Excel. The simulation was performed for the all year operation characteristic of the system.

The metrological data used for the simulation was obtained from Environment Canada (http://climate.weather.gc.ca/). Year 2014 was chosen as the period. 
The stages involved in the simulation process is as follows:

1. Heating by the GSHP considering actual COP.

2. Cooling by the GSHP considering actual COP.

3. DHW heating by the GSHP for both heating and cooling season.

4. Calculating Thermal Imbalance in the ground for the year.

The simulation was done by entering the metrological data and ground properties of an average soil. The flowchart is given on page 28 of this study. The results are presented graphically on the following pages: 


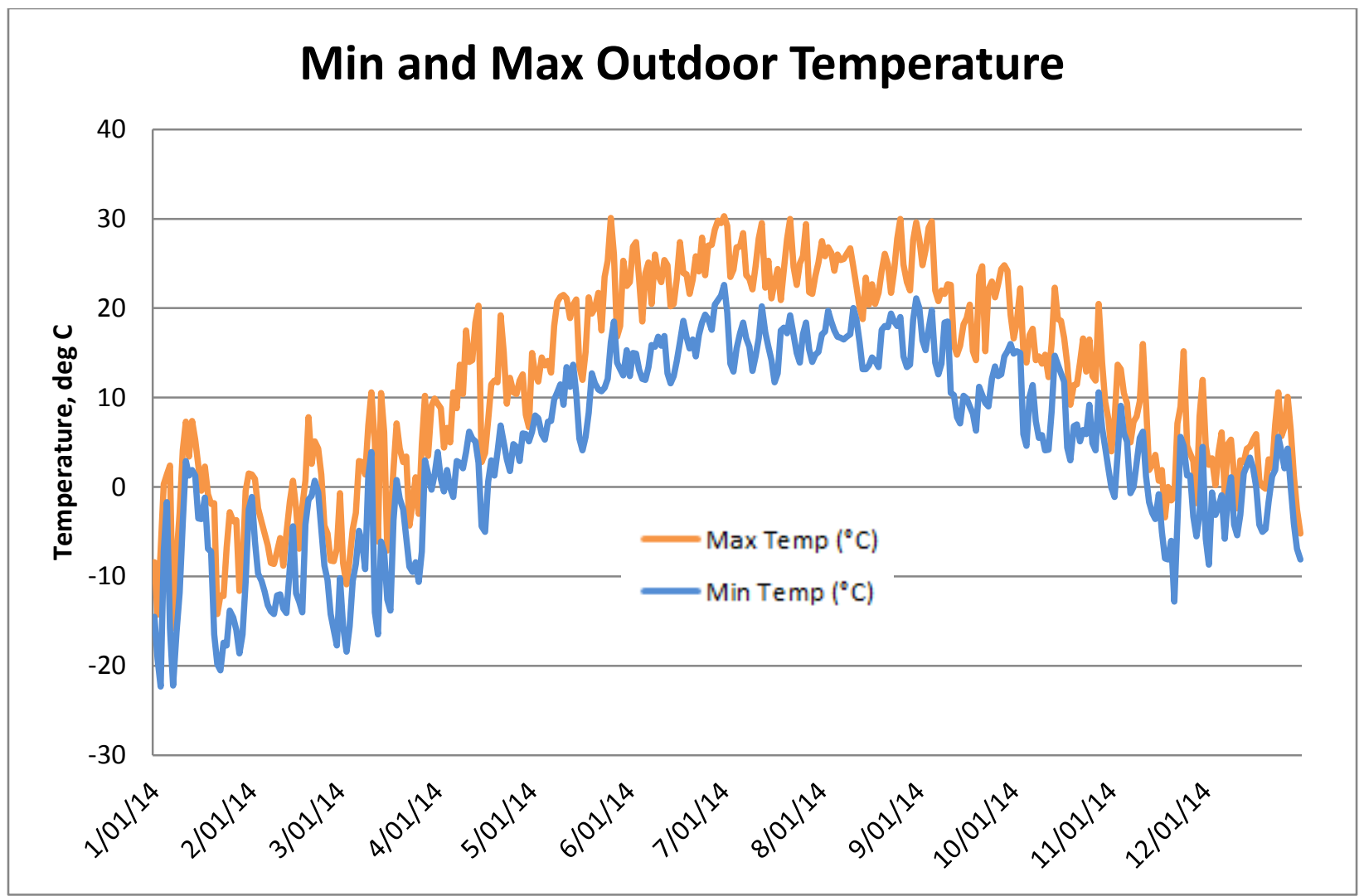

Fig: 7.1: Daily maximum and minimum outdoor temperature.

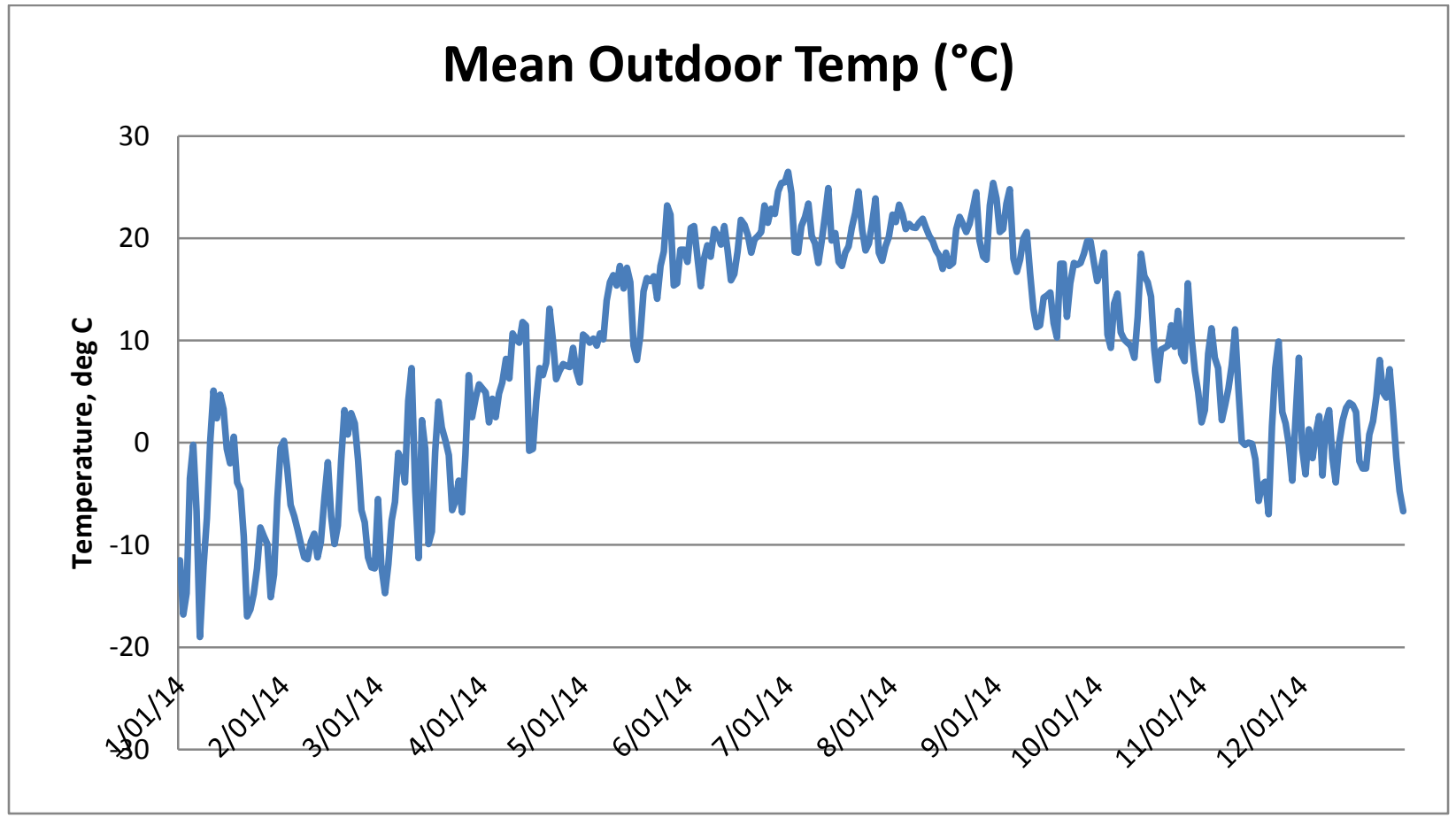

Fig: 7.2: Daily mean outdoor temperature. 


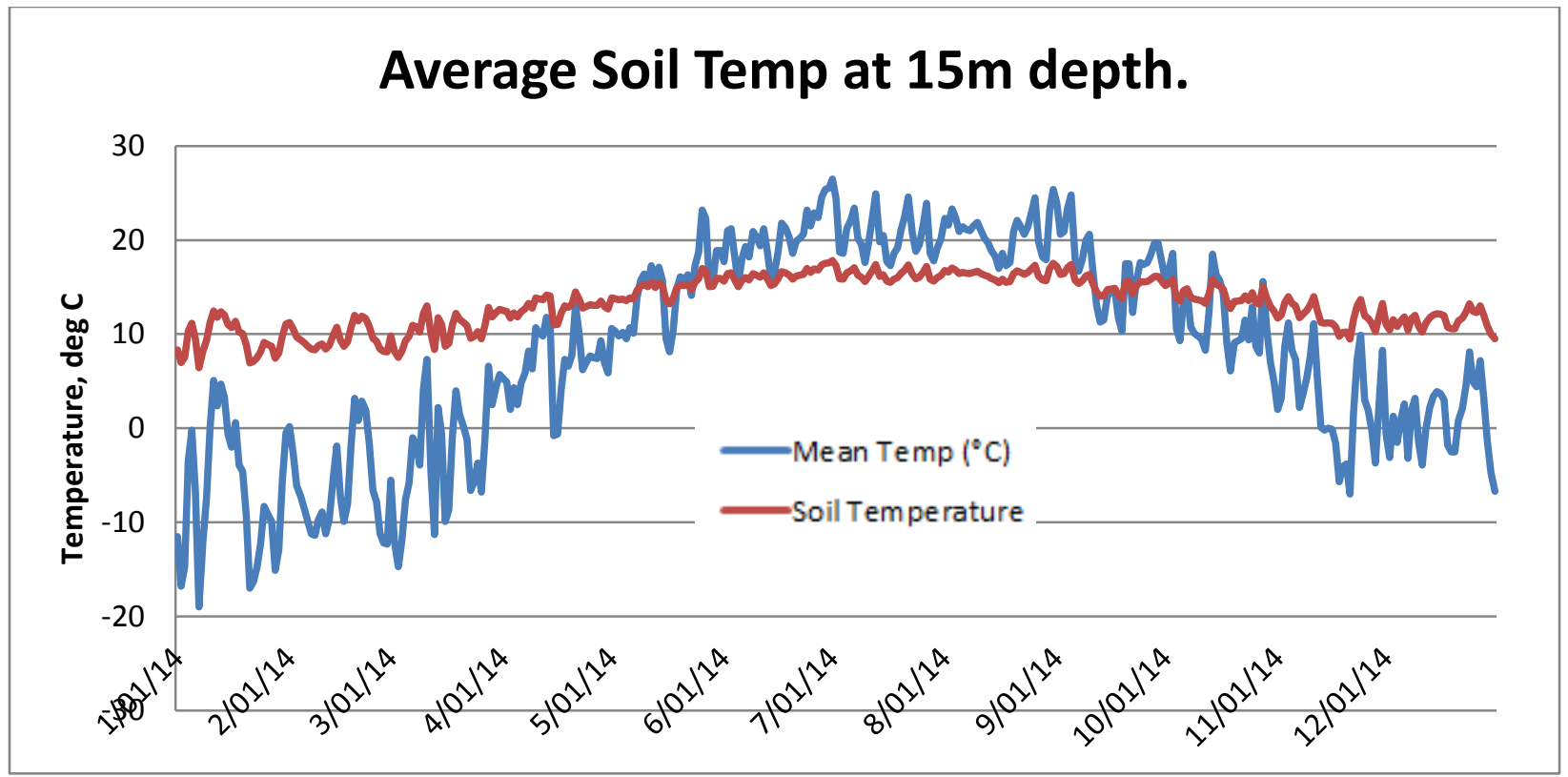

Fig: 7.3: Daily mean soil temperature at $15 \mathrm{~m}$ depth.

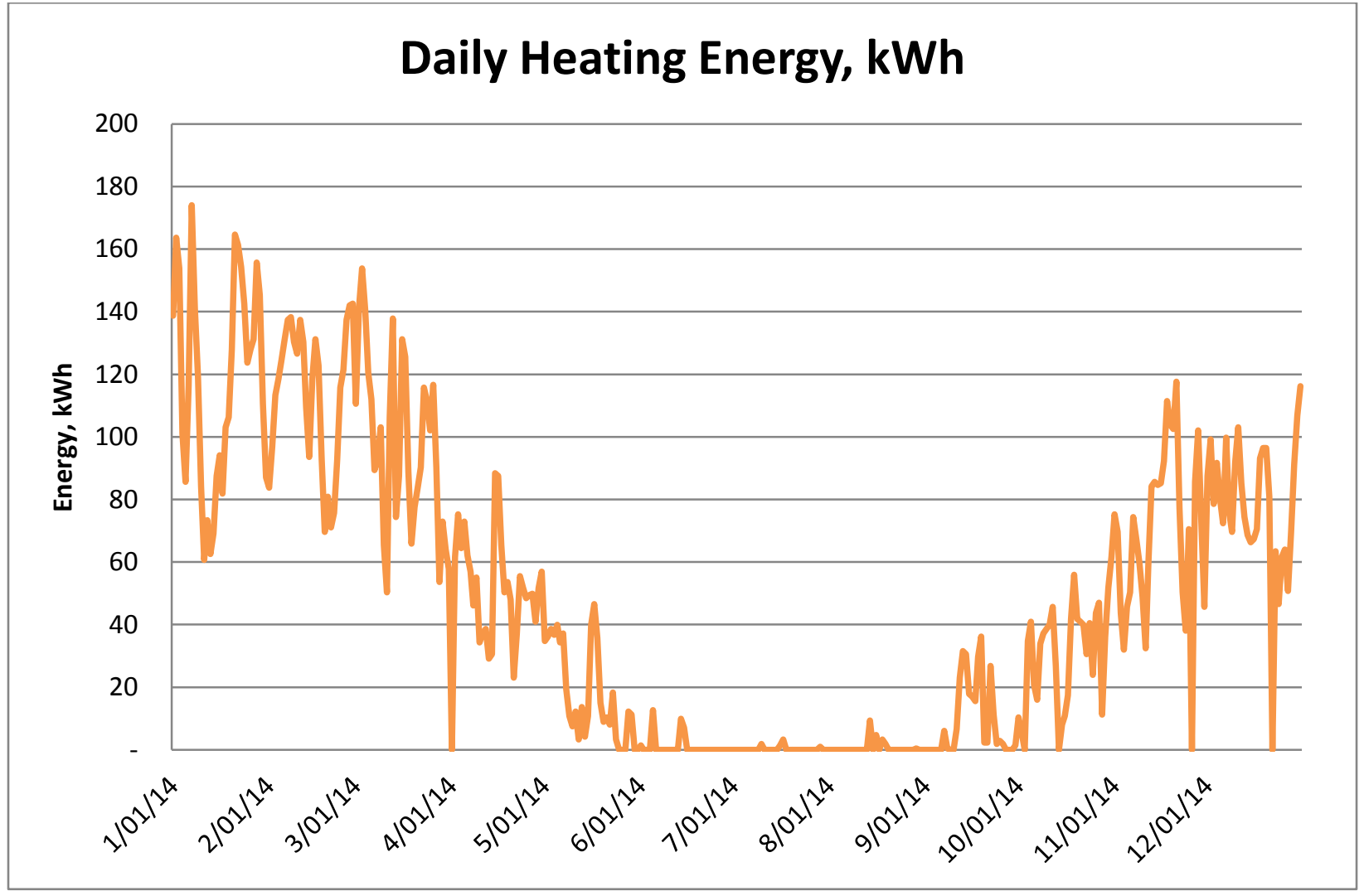

Fig: 7.4: Daily heating energy in kWh. 


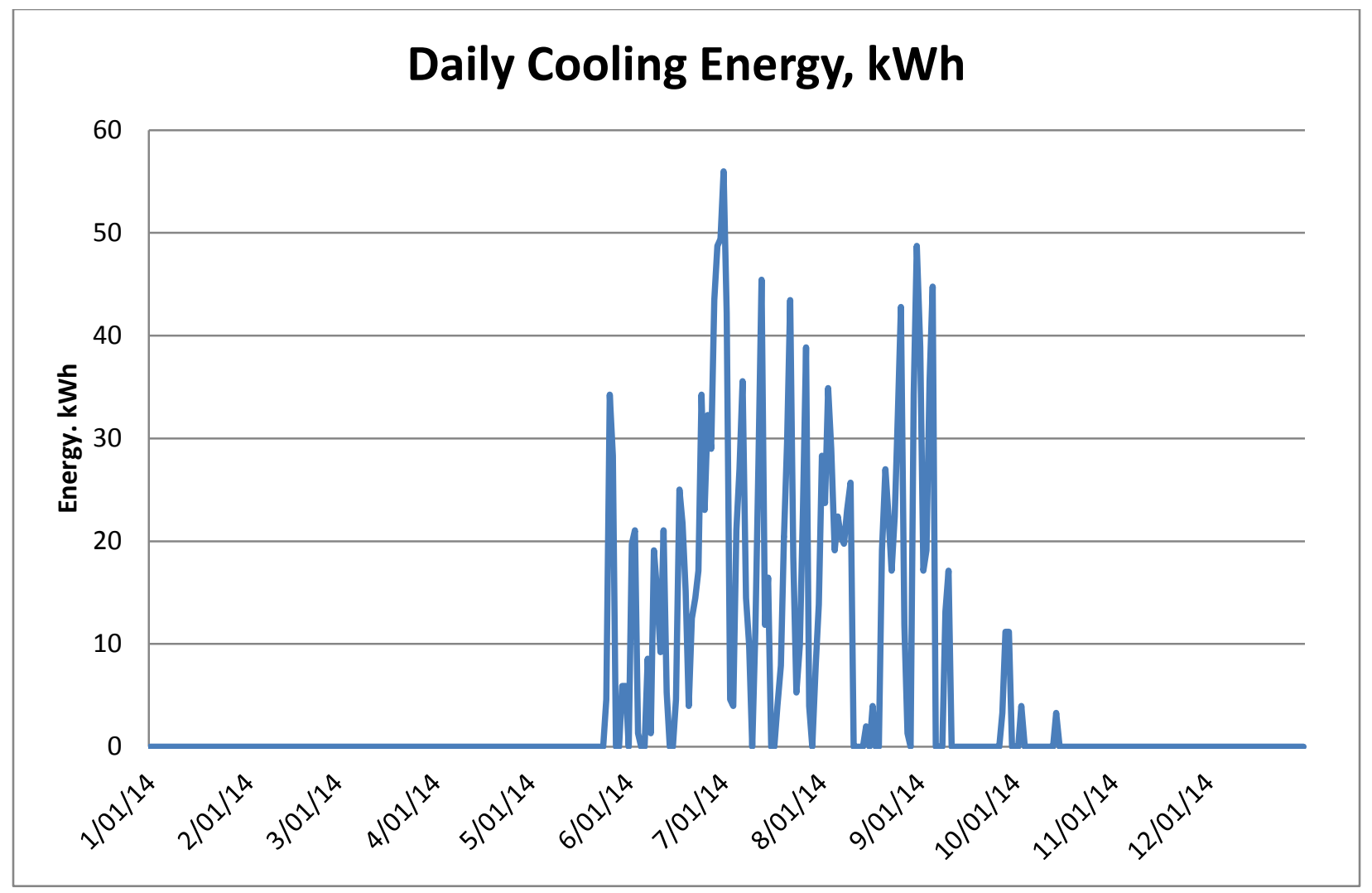

Fig: 7.5: Daily cooling energy in kWh.

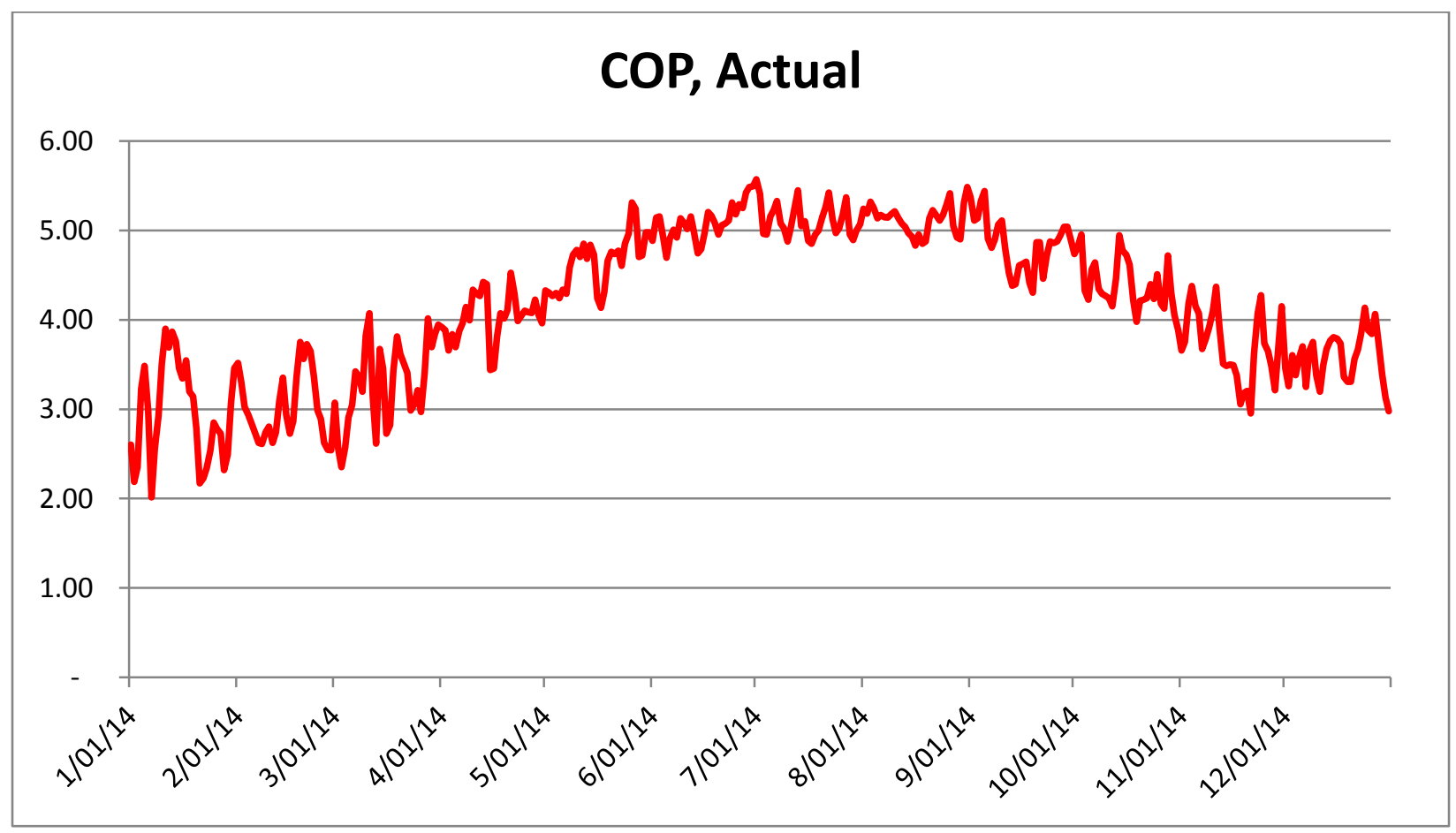

Fig: 7.6: Actual COP for the whole year. 


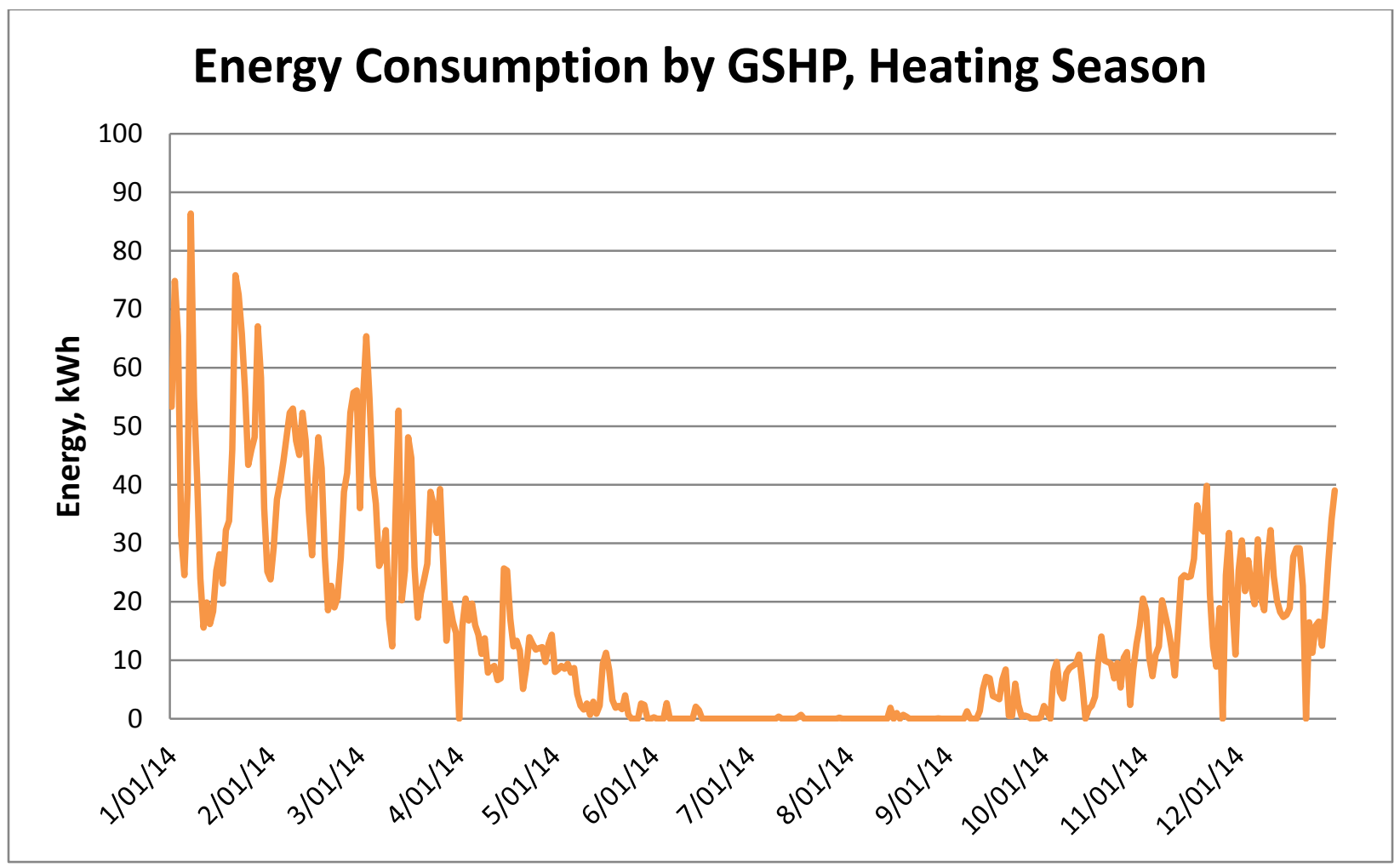

Fig: 7.6: Energy consumption by the GSHP for the heating season.

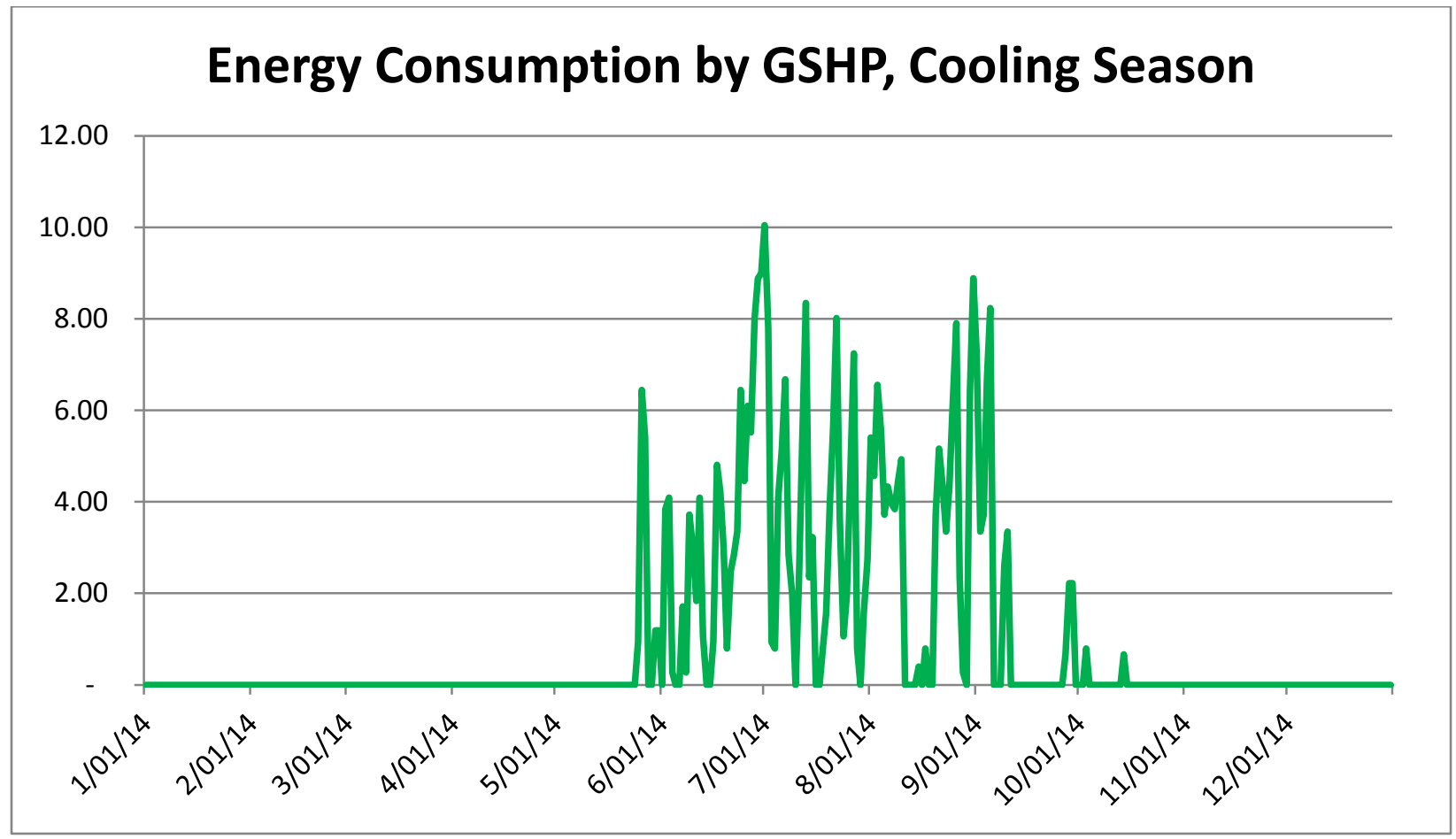

Fig: 7.8: Energy consumption by the GSHP for the Cooling season. 


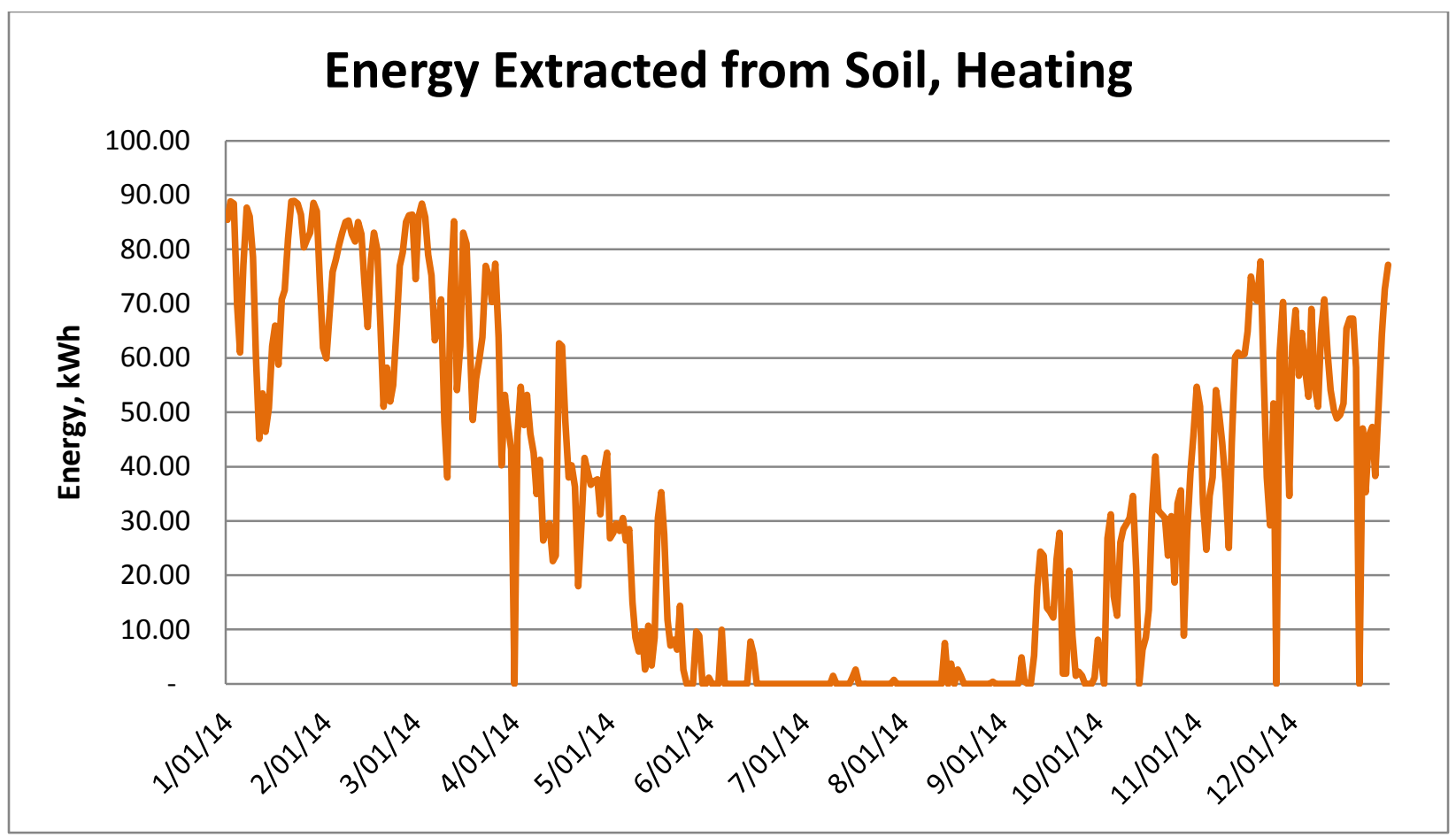

Fig: 7.9: Energy consumption by the GSHP for the Cooling season.

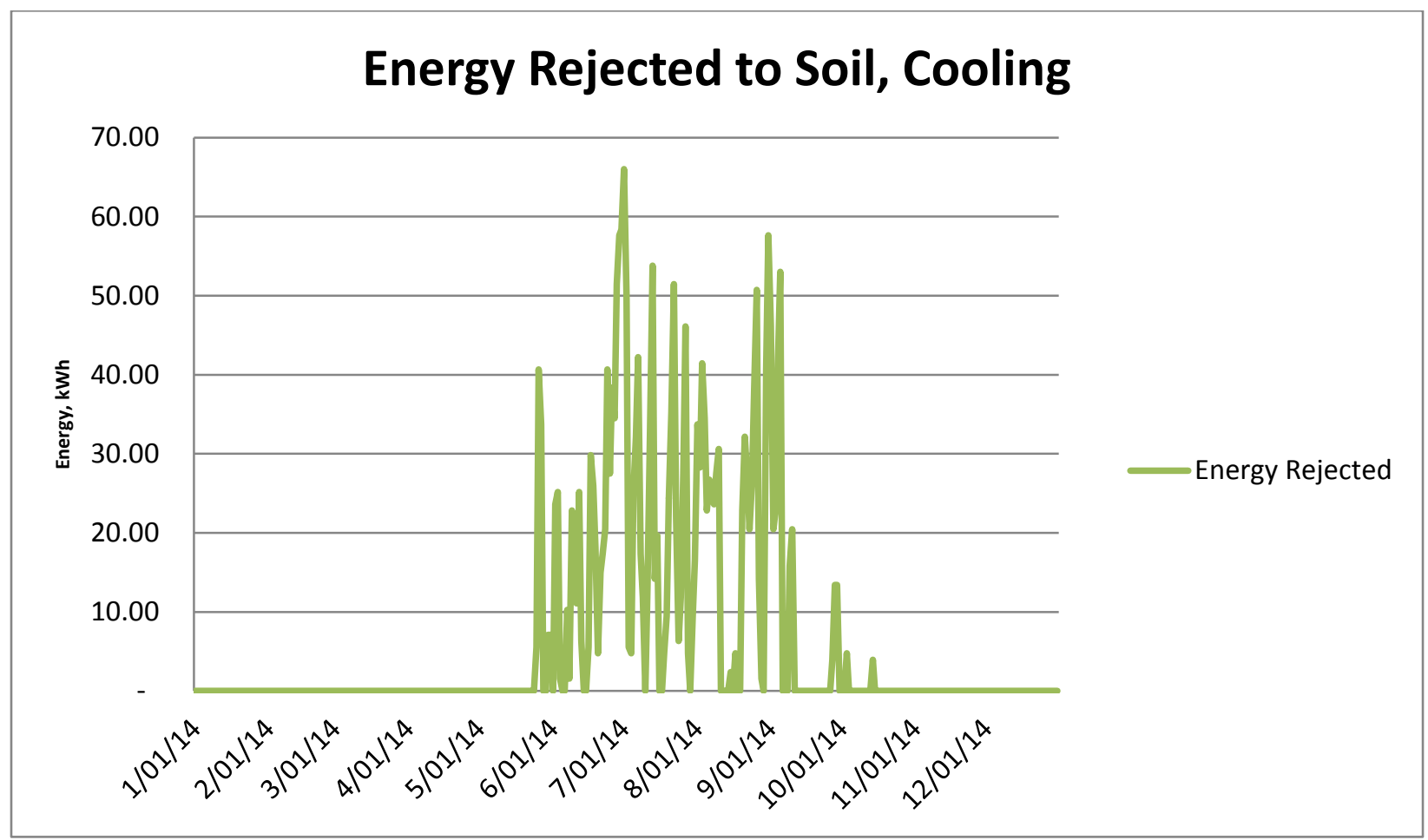

Fig: 7.10: Energy consumption by the GSHP for the Cooling season. 


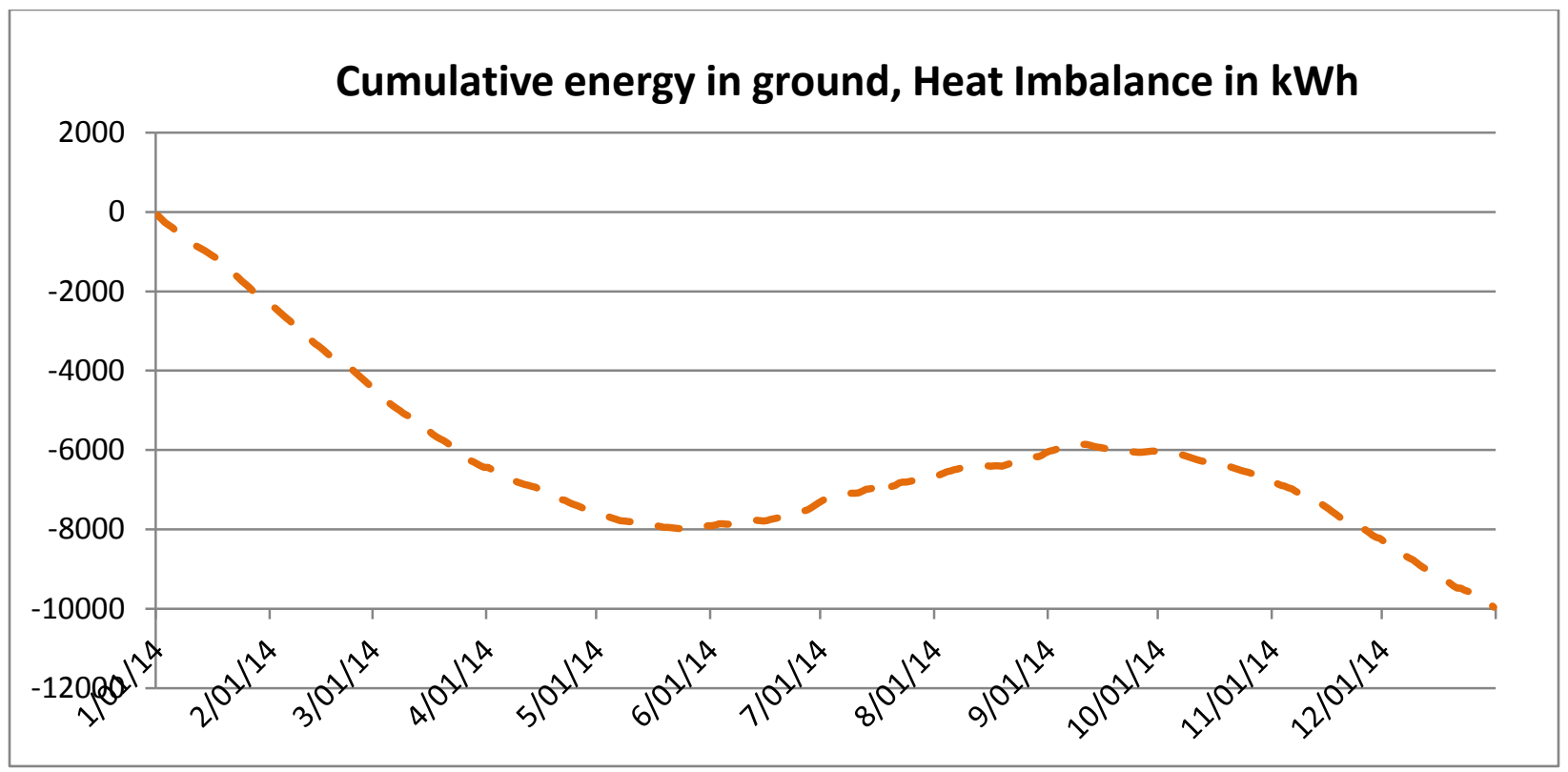

Fig: 7.11: Cumulative energy in ground.

The numerical values of the findings are listed below:

Theoretical soil temperature

Simulated Soil Temperature

Rated COP of Heating or cooling

Simulated COP

Electric energy used by GSHP, heating

Electric energy used by GSHP, cooling

Greenhouse Gas Emissions

Heating season ground energy extraction

Cooling season ground energy rejection

Heat Imbalance for the year
$=11 \cdot 2{ }^{\circ} \mathrm{C}$

$=\min 6.45^{\circ} \mathrm{C}, \max 17.83^{\circ} \mathrm{C}$

$=3.5$

$=\min 2.02, \max 5.57$, average 3.15

$=5,510.08 \mathrm{kWh}$

$=358.09 \mathrm{kWh}$

$=7.54$ tons/year

$=12,196.25 \mathrm{kWh}(3,387.85 \mathrm{MJ})$

$=2,237.62 \mathrm{kWh}(621.56 \mathrm{MJ})$

$=(9,958.63) \mathrm{kWh} \quad(-2,766.29 \mathrm{MJ})$ 


\subsection{Annual Energy Consumption by the Systems:}
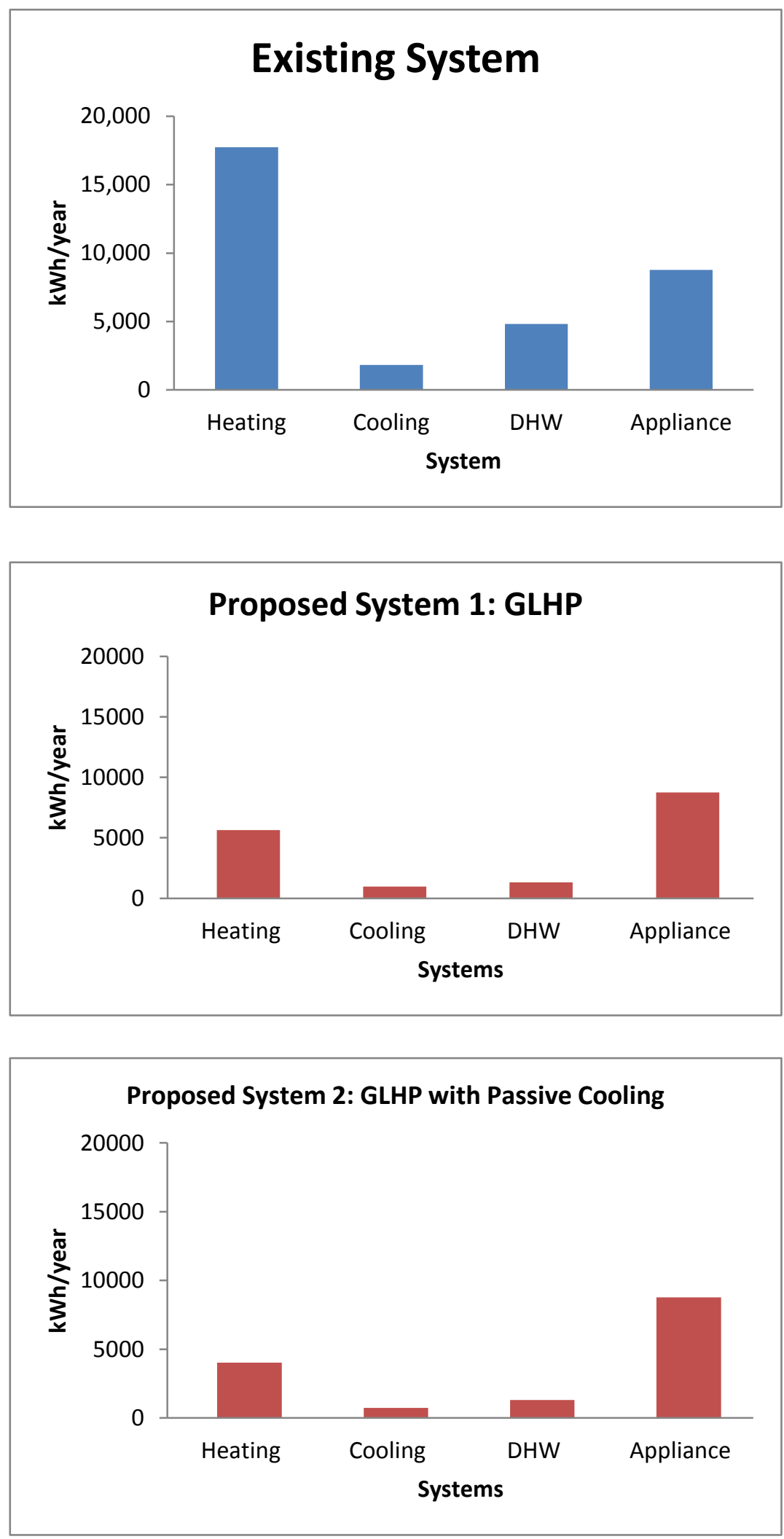


\subsection{Results comparison:}

The total energy requirement for the house is listed in the following table for all 3 systems:

\begin{tabular}{|c|c|c|c|}
\hline Item: & Existing System & System 1: GLHP & $\begin{array}{l}\text { System 2: GLHP } \\
\text { with Passive H/C }\end{array}$ \\
\hline Heating Energy & $17,729.64 \mathrm{kWh}$ & $5,636.31 \mathrm{kWh}$ & $4,026.33 \mathrm{kWh}$ \\
\hline Cooling Energy & $1,831.07 \mathrm{kWh}$ & $977.38 \mathrm{kWh}$ & $728.35 \mathrm{kWh}$ \\
\hline Appliance Energy & $8,760.00 \mathrm{kWh}$ & $8,760.00 \mathrm{kWh}$ & $8,760.00 \mathrm{kWh}$ \\
\hline DHW Energy & $4,826.00 \mathrm{kWh}$ & 1,309.92 kWh & 1309.92 kWh \\
\hline Total Electric Energy & $33,146.71 \mathrm{kWh}$ & $16,683.61 \mathrm{kWh}$ & $14,824.60 \mathrm{kWh}$ \\
\hline $\begin{array}{l}\text { Green House Gas } \\
\text { Emission }\end{array}$ & 14.80 tonnes/year & 7.54 tonnes/year & 6.11 tonnes/year \\
\hline
\end{tabular}

Total Electric Energy consumption is reduced by $46 \%$ for the GLHP system and $52 \%$ for GLHP with Passive Heating/Cooling. The greenhouse gas emission has the same trend.
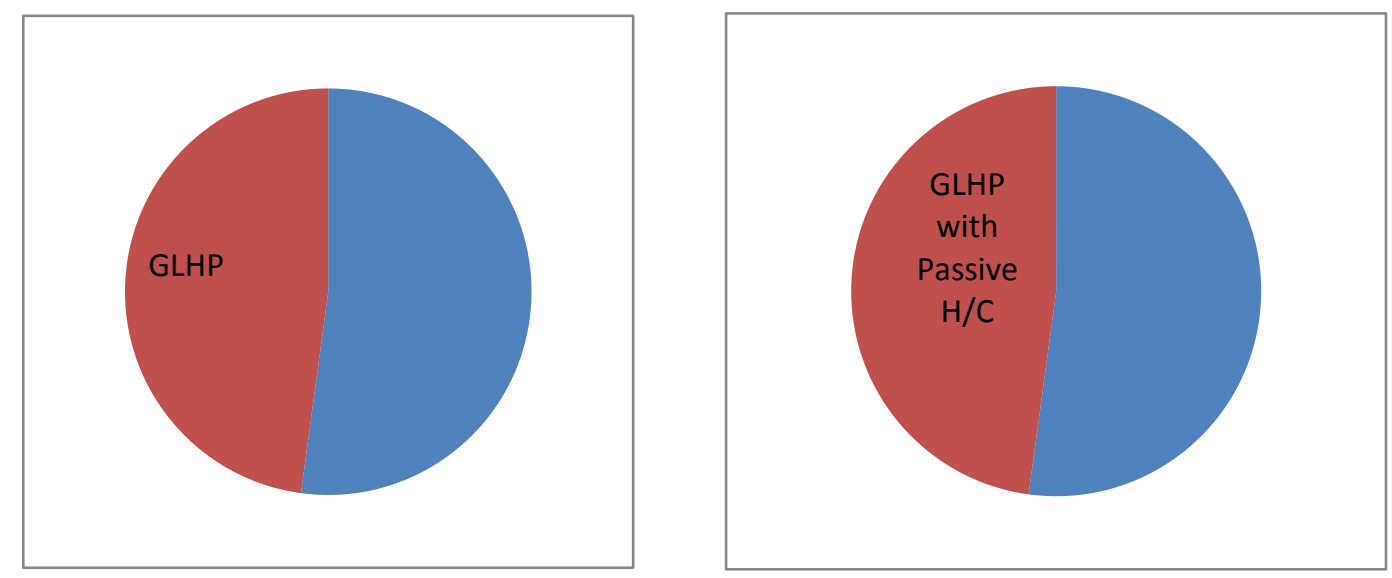

Overall Heat Imbalance of the ground for house for an year is 9,958.63 kWh or 2,766.29 MJ extracted. 


\subsection{Annual Heat Imbalance: Methods to reduce}

Thermal degradation leads to colder ground temperatures. This low ground temperatures can lower down the EWTs so it could fall down to the bottom end of the heat pump operational ranges. In some cases EWTs could be too low for the heat pump to operate efficiently. This will make the heat pump unable to achieve the manufacturer COP.

Excessive heat extraction from the ground in colder climate could potentially create permafrost or seasonal frost. The creation of permafrost will lead to the damage of structure, ground loop and utility lined and will lower the COP. Not enough study was made in this regard but reports and articles address seasonal imbalances of heat extracted versus heat returned to the ground and the soil freezing during the winter season. However, documented evidence of permanent soil degradation is scarce, and few long-term studies have been done to determine the effect of ground loops on the soil thermal regime.

\section{Hybrid Systems}

When a GSHP is combined with another heat source or sink it is called hybrid system. In the hybrid system both the ground Source and the other source are used for heating/cooling purposes. The proportion of both these sources/sinks may not be equal.

For colder part of the world solar thermal collector could be combined with the GSHP to form the hybrid system. The solar thermal could be used for space heating in conjunction with the GSHP or if heating is not needed then could be routed to the ground for recharging the soil.

For hotter part of the world cooling tower or cooling pond could be combined with GSHP in forming the hybrid system. 


\subsection{GSHP with Solar thermal collector:}
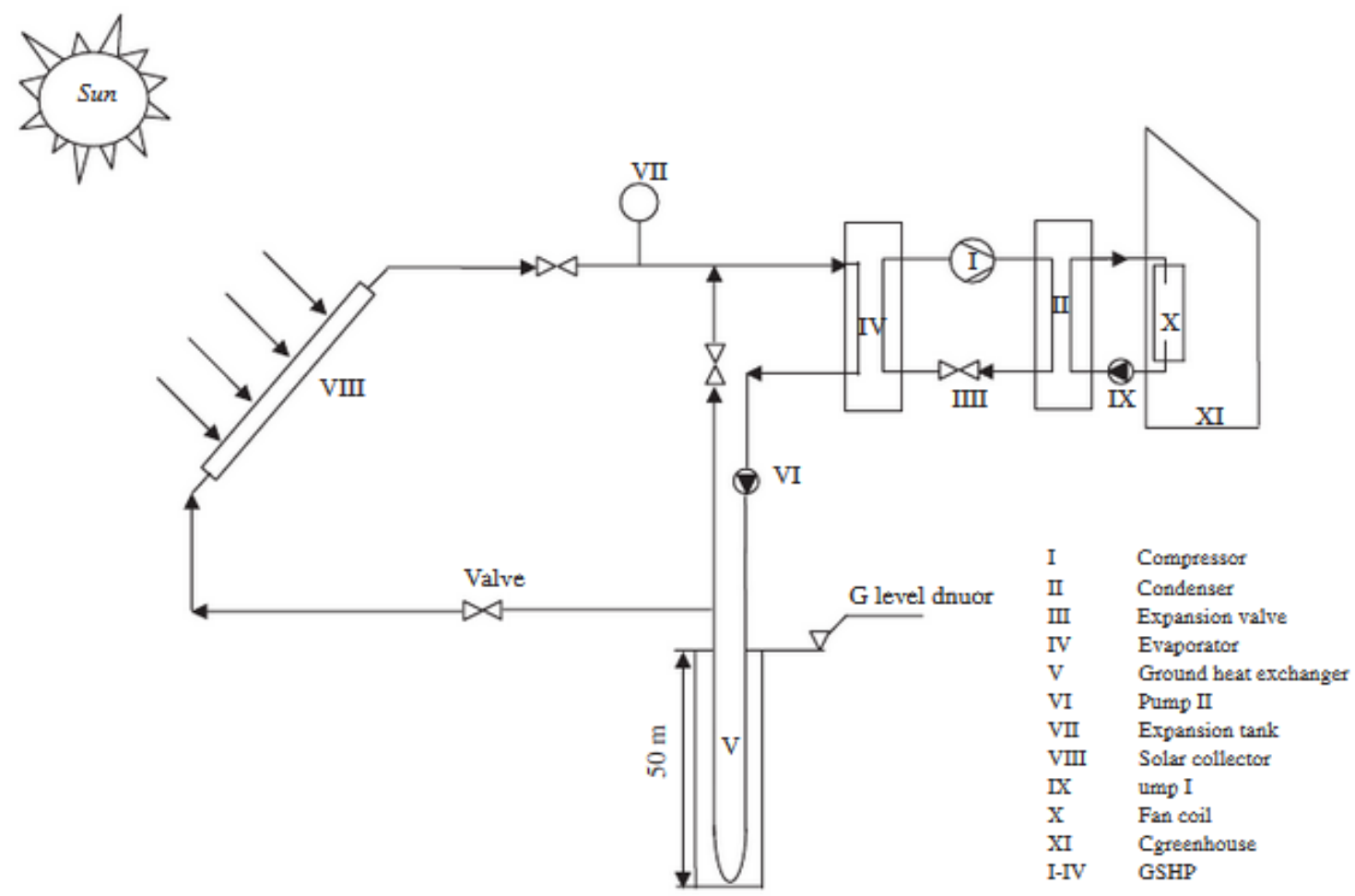

Fig: The main components and schematic of a solar assisted ground source heat pump.

\section{Basic operation:}

- Solar collector collects heat from the solar radiation.

- Collected heat is used to assist the ground loop, extra heat is pumped back to the ground.

- Lowers the heat imbalance. 


\subsection{Solar assisted ground source heat pump with latent heat storage system:}

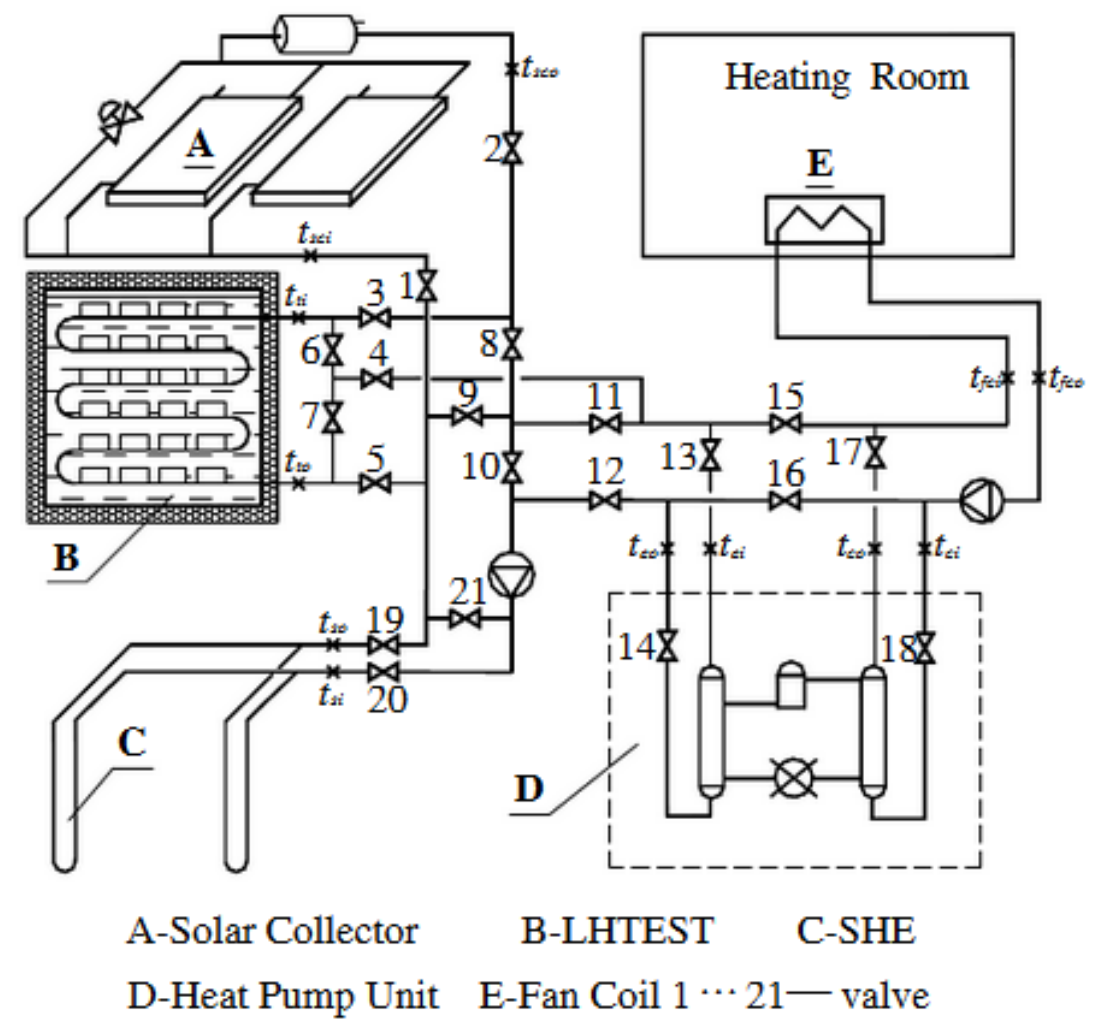

Basic operation:

The figure above shows that the system consists of five parts, which are solar collector, Latent Heat Energy Storage Tank (LHEST), Soil Heat Exchanger, heat pump unit, and fan coil. The solar collector panel collects energy from sun. The solar collector is double glass covered endothermal panel. The solar collector is placed to collect the maximum heat in the winter so that it can contribute the most in the heating mode. The connection is parallel so that the collected heat is maximum and the pressure loss in the system is minimum.

There is a liquid to liquid heat exchanger which collects the heat from the solar collector for the phase change material. The phase change material is a water and Calcium Chloride mixture $\left(\mathrm{CaCl}_{2} \cdot 6 \mathrm{H}_{2} \mathrm{O}\right)$. Latent heat energy storage is chosen because it can store huge energy in less volume of material. The phase change material is encapsulated. Thermal insulation is placed around the tank. The vertical U-tube exchanger is the soil heat exchanger. 


\section{Executive Summary:}

The study was to improve the energy efficiency of an existing energy efficient house. Energy efficiency in terms of less electrical/fuel energy use and less Greenhouse gas emission. The house in the study was heated by electric Baseboard heaters. Cooling was done by conventional air to air refrigeration cooling system. Domestic hot water was provided by electric gas furnace/boiler. The house is equipped with all energy efficient appliances and the ventilation / infiltration is minimum. All the insulating materials are considered of highest standard. All suggested methods for improving energy efficiency mentioned by natural Resources Canada was adopted in the house. It was considered the energy requirement of this house is in the lowest possible level.

As the energy requirement is considered the minimum we tried to find alternate energy sources which will cut down the usage of electric energy/fuel. Ground Source Heat Pump (GLHP) is proposed as the solution. GLHP uses less electric energy and brings heat/cold from the ground source which was used to heat/cool/DHW needs. Results has showed the possibilities to reduce the electric energy consumption of a house by about $56 \%$ by using GLHP.

The main drawback of Heat Pump is the lower temperature of source for the house heating. In case of boiler/furnace the air temperature is much higher than heat pump. So more airflow is required for heating/cooling. Using the existing air circulation system can restrict the airflow. Restricting airflow rates decreases efficiency and damage to the compressor can result if they are severely reduced for extended periods of time.

New heat pump systems should be designed according to established practice. If the installation is an add-on, or a conversion, the existing duct system should be carefully examined to ensure that it is adequate. All the cost and benefits of the heat pump system should be considered before buying it. Buying a heat pump may benefit the running cost of the system but the initial 
cost may be higher. It is necessary to carefully compare the running cost savings over the initial cost. A heat pump operation will save money when it is operated round the year.

The problem with the ground source heat pump with the soil is heat imbalance on a round the year basis. The heat extraction in the winter is remarkably higher than the heat rejection in the summer. This thermal imbalance can led to seasonal frost of the soil which is harmful for the structure and the ground loop itself. Two hybrid ground source heat pump system was mentioned which can minimize the imbalance. 


\subsection{Conclusion:}

A heat pump is able to meet the heating/cooling need using less electricity. It is a good choice to have a supplementary heating system such as a gas furnace, oil furnace or electric heater. This will reduce the size of the heat pump which will maximize the use of the capacity. It would be more effective to install a heat pump system with an existing gas/oil furnace heating system to reduce the energy bill. The drawback of thermal imbalance could be mitigated by modifying it to a hybrid system by adopting other renewable sources. Solar could be the best technology to be added but still requires further study.

Passive heating/cooling could be another attractive solution. It is very cheap and simple in operation. It is not possible to latent cooling by passive cooling. Future studies could be done on passive heating/cooling by using solar power produced by the house itself. Passive heating/cooling could be very effective in places where grid electricity is not present. $100 \%$ outside air circulation could be adapted with passive cooling in some part of the year.

Electric Thermal Storage (ETS) could be a very good topic for future study. The ETS heating was developed in Europe in the 1940s, and was introduced to the United States in the 1980s. This type of space-heating system is capable of providing all of a home's heating requirements by storing heat produced during the night, when utilities generally offer lower off-peak rates. Elements within the storage core heat ceramic bricks, crushed rock, or water to a predetermined temperature level to provide the heating requirements for the entire on-peak period. 


\section{Appendices}

Appendix A:

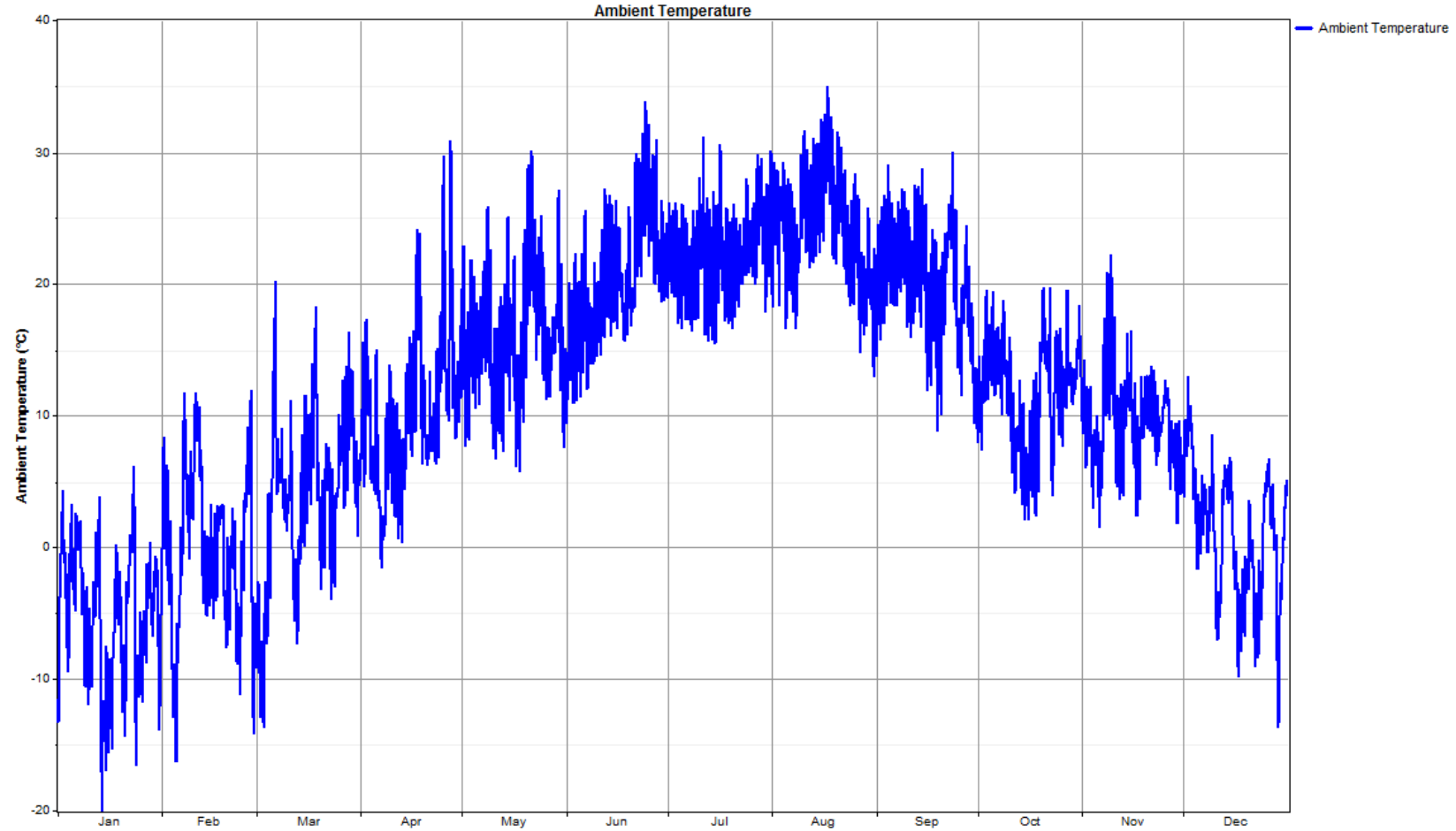

Fig: 13.4 Ambient Temperature: Annual

Temperature and Precipitation Chart for 1981 to 2010 Canadian Climate Normals TORONTO
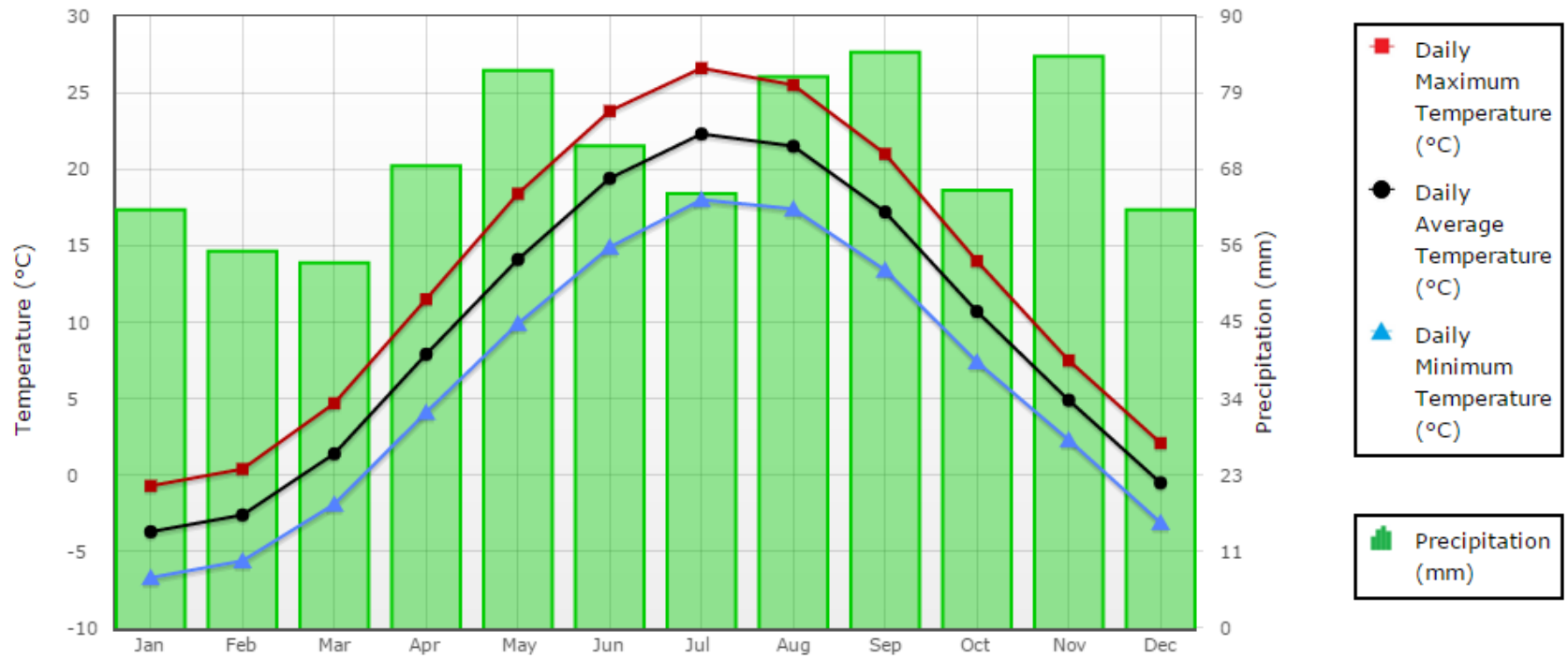

Fig: 13: 5 Ambient historical normal 


\section{Appendix: B}

Calculated Annual Energy/Fuel Consumption By The Existing Systems:

$\begin{array}{lll}\text { Primary Heating Fuel } & : & \text { Electricity } \\ \text { Equipment } & : & \text { Electric Furnace } \\ \text { Calculated Output Capacity } & : & 10.50 \mathrm{~kW} \\ \text { Design Capacity } & : & \text { Heat loss X } 1.00+0.5 \mathrm{~kW} \\ \text { Steady State Efficiency } & : & 95 \% \\ \text { Fan Mode } & : & \text { Auto } \\ \text { Electric Baseboard } & & \\ \text { Annual Energy Consumption } & & =59,120.07 \mathrm{MJ} / 0.95 \\ & & =62231.65 \mathrm{MJ} \\ & =62231.65 \mathrm{MJ} / 3.6 \mathrm{kWh} / \mathrm{MJ} \\ & =17,286.56 \mathrm{kWh} \\ \text { Circulating fan power } & =204 \mathrm{watt} \\ \text { Annual Energy consumption } & =204 \times 12 \times 181 \\ & =443.08 \mathrm{kWh}\end{array}$

Total Heating Energy absorbed by the System for Providing Heat

$$
\begin{aligned}
& =17,286.56 \mathrm{kWh}+443.08 \mathrm{kWh} \\
& =17,729.64 \mathrm{kWh}
\end{aligned}
$$

Installed Space Cooling System In The House:

$\begin{array}{lll}\text { System Type } & : & \text { Conventional A/C (Air to Air) } \\ \text { Manufacturer } & : & \text { Generic } \\ \text { Capacity } & : & 3985 \text { Watts } \\ \text { Crankcase Heater Power (watts) } & 60 \text { Watts }\end{array}$

Air Conditioner is integrated with the Heating System

Air Conditioner system Annual Energy requirement

$$
\begin{aligned}
& =\text { Cooling Energy } / \text { COP } \\
& =14790.07 \mathrm{MJ} / 2.623 \\
& =5,638.61 \mathrm{MJ} \\
& =5,638.61 / 3.6 \mathrm{kWh} \\
& =1,566.11 \mathrm{kWh}
\end{aligned}
$$


Crankcase Heater and Fan Annual Energy requirement

$$
\begin{aligned}
& =60 \mathrm{~W} \times 184 \times 24 / 1000 \mathrm{kWh} \text { [Summer duration } 184 \text { days] } \\
& =264.96 \mathrm{kWh}
\end{aligned}
$$

Total Energy Absorbed by the System for Providing Cooling

$$
\begin{aligned}
& =1,566.11 \mathrm{kWh}+264.96 \mathrm{kWh} \\
& =1831.07 \mathrm{kWh}
\end{aligned}
$$

DOMESTIC WATER HEATING SYSTEM

Primary Water Heating Fuel : $\quad$ Natural gas

Water Heating Equipment : : Induced draft fan

Energy Efficiency : $\quad 0.95$

Manufactuer : $\quad$ Generic

Tank Capacity : : 151.38 Litres

Tank Blanket Insulation $\quad$ : $\quad 0.00$ RSI

Tank Loacation : Basement

Flue Diameter $\quad$ : $\quad 76.20 \mathrm{~mm}$

Daily Hot Water Consumption, $\mathrm{m}=225$ Litres

$$
\begin{aligned}
& =225 \text { Litres x } 1 \mathrm{~kg} / \text { Litre } \\
& =225 \mathrm{~kg}
\end{aligned}
$$

Hot Water Temperature

Water Temp

Specific Heat of Water, $c p$

Domestic Water Heating Load

Annual Electricity Consumption

APPLIANCE LOADS OF THE HOUSE

Annual Appliance Load

$$
\begin{aligned}
& =60^{\circ} \mathrm{C} \text { Average City } \\
& =12^{\circ} \mathrm{C} \\
& =4.187 \mathrm{~kJ} / \mathrm{kg}^{\circ} \mathrm{C} \text { Calculated } \\
& =\mathrm{mcp}(\mathrm{ti}-\mathrm{to}) \times \text { Days in Year } \\
& =225 \times 4.187 \times(60-12) \times 365 \mathrm{~kJ} \\
& =16,505,154 \mathrm{~kJ} \\
& =16,505.15 \mathrm{MJ}
\end{aligned}
$$

$=16,505.15 \mathrm{MJ} / .95 / 3.6$

$=4,826 \mathrm{kWh}$

$=24 \times 365 \mathrm{kWh}$

$=8,760 \mathrm{kWh}$ 


\section{Appendix: C}

$\begin{array}{llll}\text { SPACE HEATING SYSTEM } & & \\ \text { Primary Space Heating Fuel } & : & \text { Electricity } \\ \text { Space Heating Equipment } & : & \text { Ground Source Heat Pump } \\ \text { Input Capacity } & : & 7.00 \mathrm{~kW} \\ \text { Heating/Cooling COP at } 8.3^{\circ} \mathrm{C} & : & 3.5 \\ \text { Crankcase Heater Power } & : & 60.00 \text { watts } \\ \text { Heat Pump Temp Cut-Off } & : & \text { Balance point } \\ \text { SPACE COOLING SYSTEM } & & \\ \text { System Type } & : & \text { Ground Source Heat Pump } \\ \text { Capacity } & : & 3925 \text { Watts } \\ \text { Rated COP } & : & 3.5 \\ \text { Sensible Heat Ratio } & : & 0.76 \\ \text { Indoor Fan Flow Rate } & : & 239.65 \text { L/s } \\ \text { Fan Power (watts) } & : & 185.73 \text { Watts } \\ \text { Crankcase Heater Power (watts): } & 60 \\ \text { Indoor Fan Operation } & : & \text { Continuous }\end{array}$

Air Conditioner is integrated with the Heating System

COMBO SPACE + DHW HEATING SYSTEM

$\begin{array}{lll}\text { Secondary Heating Fuel } & : & \text { Natural Gas } \\ \text { Equipment } & : & \text { Furnace/Boiler with continuous pilot } \\ \text { Specified Output Capacity } & : & 10.50 \mathrm{~kW} \\ \text { Steady State Efficiency } & : & 80.00 \% \\ \text { Fan Mode } & : & \text { Auto } \\ \text { ECM Motor } & : & \text { No } \\ \text { Low Speed Fan Power } & : & 0 \text { watts } \\ \text { High Speed Fan Power } & : & 327 \text { watts } \\ \text { Water Heater Temperature } & : & 60.0{ }^{\circ} \mathrm{C} \\ \text { Water Heating Energy Factor } & : & 0.6\end{array}$




$\begin{array}{lll}\text { Tank Capacity } & : & 151.4 \text { Litres } \\ \text { Tank Blanket Insulation } & : & 20.0 \text { RSI } \\ \text { Tank Location } & : & \text { Basement } \\ \text { Circulation Pump (Calculated) } & : & 92.0 \text { watts }\end{array}$

\section{ANNUAL SPACE HEATING LOAD CALCULATION}

Annual Heating Energy required by house $=17,286.56 \mathrm{kWh}$

Energy Input to GLHP

$$
\begin{aligned}
& =\text { Heating Energy } / \text { COP } \\
& =17,286.56 \mathrm{kWh} / 3.5 \\
& =4,939.02 \mathrm{kWh}
\end{aligned}
$$

Circulating fan power for GLHP

$$
\begin{aligned}
\text { Circulating fan power for GLHP } & =204 \text { Watt }+30 \% \text { of } 204 \text { Watt } \\
& =265.2 \mathrm{Watt} \\
\text { Annual Energy consumption by fan } & =265.2 \times 12 \times 181 \\
& =576.01 \mathrm{kWh}
\end{aligned}
$$

Crankcase Heater and Fan Annual Energy requirement

$$
=120 \mathrm{~W} \times 181 \times 24 / 1000 \mathrm{kWh}
$$

[Winter duration 181 days]

$$
=521.28 \mathrm{kWh}
$$

Total Energy absorbed by the system for providing Heat

$$
\begin{aligned}
& =4,939.02 \mathrm{kWh}+576.01 \mathrm{kWh}+521.28 \mathrm{kWh} \\
& =5,636.31 \mathrm{kWh}
\end{aligned}
$$

Annual Space Cooling Summary

Air Conditioner system Annual Energy requirement

$$
\begin{aligned}
& =\text { Cooling Energy } / \text { COP } \\
& =1,566.11 \mathrm{kWh} / 3.5 \\
& =447.46 \mathrm{kWh}
\end{aligned}
$$

Crankcase Heater and Fan Annual Energy requirement

$$
=120 \mathrm{~W} \times 184 \times 24 / 1000 \mathrm{kWh}
$$

[Summer duration 184 days]

$$
=529.92 \mathrm{kWh}
$$


Total Energy absorbed by the System for Providing Cooling

$$
\begin{aligned}
& =447.46 \mathrm{kWh}+529.92 \mathrm{kWh} \\
& =977.38 \mathrm{kWh}
\end{aligned}
$$

Domestic Water Heating System

Domestic Water Heating Load

$$
\begin{aligned}
& =225 \times 4.187 \times(60-12) \times 365 \mathrm{~kJ} \\
& =16,505,154 \mathrm{~kJ} \\
& =16,505.15 \mathrm{MJ}
\end{aligned}
$$

Annual Electricity Consumption =16,505.15 MJ / 3.5/3.6 kWh

$$
=1309.92 \mathrm{kWh}
$$

Appliance Loads Of The House

Annual Appliance Load

$$
\begin{aligned}
& =24 \times 365 \mathrm{kWh} \\
& =8,760 \mathrm{kWh}
\end{aligned}
$$

Summary for Proposed System 1:

Energy Consumption By The Systems:

Annual Energy/Fuel Consumption By The Systems:

$$
\begin{array}{ll}
\text { Annual Space Heating Energy Consumption } & =5,636.31 \mathrm{kWh} \\
\text { Annual Space Cooling Energy Consumption } & =977.38 \mathrm{kWh} \\
\text { Annual APPLIANCE Load Energy Consumption } & =8,760.00 \mathrm{kWh} \\
\text { Annual DHW Heating Energy Consumption } & =1309.92 \mathrm{kWh} \\
\text { Total: } & =16,683.61 \mathrm{kWh}
\end{array}
$$

Annual Greenhouse Gas Emissions

$$
=7.54 \text { tonnes/year }
$$

(calculated by the Software HOT 2000)

\section{ANNUAL COST OF ENERGY}

Assumption:

Cost of Electricity

$$
=\$ 0.06 / \mathrm{kWh}
$$

Total cost

$=\$ 1,001.02$

Estimated Greenhouse Gas Emissions

$=7.54$ tonnes/year 


\section{Appendix: D}

System Specifications And Calculations: Space Heating/Cooling System

Primary Space Heating/Cooling Fuel : $\quad$ Electricity

Space Heating/Cooling Equipment $\quad$ : $\quad$ Passive Heating/cooling by Ground Source and GSHP

Input Capacity at $8.3^{\circ} \mathrm{C} \quad$ : $\quad 7.00 \mathrm{~kW}$

Adjusted Capacity at $0.0^{\circ} \mathrm{C} \quad: \quad 7.00 \mathrm{~kW}$

Input COP of Passive system : $\quad 28$

Heating/Cooling COP of GSHP $\quad: \quad 3.5$

Annual Space Heating Load Calculation

Average ground temperature in the heating/cooling season was calculated as $11.20 \mathrm{C}$ round the year.

The heating will be done in two stages: Passive heating and GLHP heating.

The part of passive heating is

$=(11.2-3.0506) / 18.1381$

$=48 \%$ GLHP Heating is

$=52 \%$

Annual Energy required by house

$=17,286.56 \mathrm{kWh}$

Passive Heating Part

$=17,286.56 \times 48 \%$

$=8,297.55 \mathrm{kWh}$

Energy Required for passive heating

$=8,297.55 \mathrm{kWh} / 23$

$=360.76 \mathrm{kWh}$

GLHP Heating Part

$=17,286.56 \mathrm{kWh} \times 52 \%$

$=8,989.01 \mathrm{kWh}$

Energy Required for GLHP heating

$=8,989.01 \mathrm{kWh} / 3.5$

$=2,568.28 \mathrm{kWh}$

Circulating fan power for Passive/GLHP

$=204$ Watt $+30 \%$ of 204 Watt

$=265.2$ Watt

Annual Energy consumption by fan

$=265.2 \times 12 \times 181$

$=576.01 \mathrm{kWh}$

Crankcase Heater and Fan Annual Energy requirement

$=120 \mathrm{~W} \times 181 \times 24 / 1000 \mathrm{kWh}$

[Winter duration 181 days] 
$=521.28 \mathrm{kWh}$

Total Heating Energy Provided by the system

$$
\begin{aligned}
& =360.76+2,568.28 \mathrm{kWh}+576.01 \mathrm{kWh}+521.28 \mathrm{kWh} \\
& =4,026.33 \mathrm{kWh}
\end{aligned}
$$

Annual Space Cooling Summary

Passive cooling will cool $100 \%$ of sensible cooling but cannot do latent cooling. So it is standard practice to consider the GLHP to be in operation for $40 \%$ of its standard energy consumption.

Energy required for Passive cooling

$=447.46 \mathrm{kWh} / 23$

$=19.45 \mathrm{kWh}$

Energy required for GLHP cooling

$=447.46 \times 40 \%$

$=178.98 \mathrm{kWh}$

Crankcase Heater and Fan Annual Energy requirement

$=120 \mathrm{~W} \times 184 \times 24 / 1000 \mathrm{kWh}$

[Summer duration 184 days]

$=529.92 \mathrm{kWh}$

Total Energy used by the System for Providing Cooling

$$
\begin{aligned}
& =19.45 \mathrm{kWh}+178.98 \mathrm{kWh}+529.92 \mathrm{kWh} \\
& =728.35 \mathrm{kWh}
\end{aligned}
$$

Domestic Water Heating System

Domestic Water Heating Load

$$
\begin{aligned}
& =225 \times 4.187 \times(60-12) \times 365 \mathrm{~kJ} \\
& =16,505,154 \mathrm{~kJ} \\
& =16,505.15 \mathrm{MJ} \\
& =16,505.15 \mathrm{MJ} / 3.5 / 3.6 \mathrm{kWh} \\
& =1309.92 \mathrm{kWh}
\end{aligned}
$$

Annual Energy consumption 


\section{References:}

[1] RETscreen International, ed. (2005). "Ground-Source Heat Pump Project Analysis". Clean Energy Project Analysis: RETscreen Engineering \& Cases Textbook. Natural Resources Canada. ISBN 0-66239150-0. Catalogue no.: M39-110/2005E-PDF. Retrieved 20 September 2015.

[2] R. Bertani, "GeOthermal ENERgY: AN OVERVIEW ON RESOURCES AND POTENTIAL," pp. 11-18, 2010.

[3] Chiasson, A.D. (1999). "Advances in modeling of ground source heat pump systems" (PDF). Oklahoma State University. Retrieved 23 September 2015.

[4] Fridleifsson, Ingvar B (2001), "Geothermal energy for the benefit of the people", Renewable and Sustainable Energy Reviews 5 (3): 299, doi:10.1016/S1364-0321(01)00002-8.

[5] http://www.nrcan.gc.ca/energy/efficiency/housing/home-improvements/17725. Retrieved 10 October 2015.

[6] Kavanaugh, Steve; Gilbreath, Christopher (December 1995). Joseph Kilpatrick, ed. Cost Containment for Ground-Source Heat Pumps. Retrieved 24 September 2015.

[7] ASHRAE, Handbook, Fundamentals, American Society of Heating, Refrigerating and AirConditioning Engineers, Inc., 1791 Tullie Circle, N.E., Atlanta, GA, USA, 1981.

[8] http://www.polarbearmechanicalsj.com/heating/furnace-repair/electric-furnace.html, Retrieved 11 October 2015.

[9] NRCan, Residential Earth Energy Systems: A Buyer's Guide, Natural Resources Canada's Renewable and Electrical Energy Division, ISBN 0-662-30980-4, Cat. No. M92-236/2001E, Ottawa, ON, Canada, 41 pages, 2002.

[10] http://www.goodmanmfg.com/HeatingCooling101/HowaCentralbrACWorks.aspx, Retrieved 23 September 2015.

[11] http://www.nrcan.gc.ca/energy/publications/efficiency/residential/air-conditioning/6051\#central Retrieved 12 October 2015.

[12] http://www.nrel.gov/buildings/residential.html, Retrieved 1 November 2015. 
[13] http://www.oit.edu/orec/geo-heat-center, Retrieved 3 November 2015.

[14] http://www.icax.co.uk/Mean_Annual_Air_Temperature.html, Retrieved 9 November 2015.

[15] http://energy.gov/energysaver/energy-saver, Retrieved 1 November 2015.

[16] http://cres-energy.org/techbasics/geothermal_div1.html, Retrieved 7 November 2015.

[17] http://www.igshpa.okstate.edu/about/, Retrieved 5 November 2015.

[18] http://www.icax.co.uk/interseasonal_heat_transfer.html, Retrieved 28 November 2015.

[19] http://www.zonneterp.nl/english/index_uk.html, Retrieved 17 November 2015.

[21] https://www.ahridirectory.org/ahriDirectory/pages/wbahp/defaultSearch.aspx, Retrieved 25 November 2015.

[22] http://www.eea.europa.eu/publications/eea_report_2008_6, Retrieved 19 November 2015.

[23] http://www.ec.gc.ca/pdb/ghg/inventory_report/2004_report/ta9_7_e.cfm, Retrieved 30 November 2015.

[24] http://adsabs.harvard.edu/abs/2011Grund..16...13B, Retrieved 26 September 2015.

[25] http://www.telegraph.co.uk/news/worldnews/1583323/Geothermal-probe-sinks-Germancity.html, Retrieved 11 September 2015.

[26] http://openthermal.net/md/, Retrieved 1 October 2015.

[27] http://www.capitalelec.com/Energy_Efficiency/ground_source/index.html, Retrieved 5 October 2015.

[28] http://www.igshpa.okstate.edu/, Retrieved 18 October 2015.

[29] http://www.polarbearmechanicalsj.com/heating/furnace-repair/electric-furnace.html., Retrieved 17 October 2015.

[30] http://www.engineeringtoolbox.com/heat-loss-buildings-d_113.html., Retrieved 21 September 2015. 


\section{Glossary:}

House - a building for human habitation, especially one that is lived in by a family or small group of people.

Energy - is the capacity of a physical system to perform work. In this report is to provide heating, cooling, hot water, lighting etc.

Joule - $\quad$ A unit to measure Energy. Joule is a relatively small amount of energy. 4,184 Joules are required to raise the temperature of 1 litre of water by 1 degree Celsius.

MJ - $\quad$ is short form of Mega Joule. $1 \mathrm{MJ}=10^{6}$ joule

watt (W) -The watt is the basic unit of measurement for electric power. The heating capacity of electric heating systems is usually expressed in kilowatts (kW). One kW equals 1000 watts.

kWh - Kilo Watthour is the measure of electric energy. It is equivalent to the energy taken by a $1 \mathrm{~kW}$ load for 1 hour.

TWh - Terra Watt Hour is measure of Electric Energy. $1 \mathrm{TWh}=10^{9} \mathrm{kWh}$.

Ampere - Electric flow is called current and is expressed in amperes. The short form is A, although amp is also used.

volt (V) - A volt is the basic unit of measurement for voltage or potential difference. Voltage causes an electric current to flow.

Sensible heating/cooling

- means the heating where temperature change can be noticed.

\section{Latent heating/cooling}

- means the addition/removal of moisture from the air.

COP - Coefficient of Performance of a heating/cooling system.

Heat Pump- Uses electrical Energy to carry heat from colder place to hotter place.

GLHP - Ground Loop Heat Pump, carries heat/cold from underground as the source. (

AFUE) - $\quad$ Annual Fuel Utilization Efficiency.

Ton - A ton is a measure of cooling capacity. It is equivalent to $3.5 \mathrm{~kW}$ or $12000 \mathrm{Btu} / \mathrm{h}$. 